\title{
Age-Related Differences in Word Recognition Task according to the Interference Types: Evidence from Eye-Tracking
}

\author{
Hye Lyun Jo, Jee Eun Sung \\ Department of Communication Disorders, Ewha Womans University, Seoul, Korea
}

Correspondence: Jee Eun Sung, PhD Department of Communication Disorders, Ewha Womans University, 52 Ewhayeodae-gil, Seodamun-gu, Seoul 03760, Korea

Tel: $+82-2-3277-2208$

Fax: +82-2-3277-2122

E-mail: jeesung@ewha.ac.kr

Received: January 7, 2019

Revised: February 18, 2019

Accepted: February 28, 2019

This paper was extracted from the Master's thesis of the first author (2018).

This work was supported by the National Research Foundation of Korea Grant funded by the Korean Government (NRF-2017S1A2A2038375)

\begin{abstract}
Objectives: There is considerable controversy with respect to language processing in the elderly. The purpose of the study was to investigate age-related differences in word recognition tasks according to interference types with Eye-tracker. Methods: A total of 46 participants (24 young and 22 elderly adults) participated in the study. A word recognition task and an online eye-tracking analysis were used. The stimuli consisted of 80 Korean nouns with four types: target, phonologically related objects to the target, semantically related objects to the target, and unrelated objects. Each critical trial display included four types. Participants were asked to select one of the pictures after the target was auditorily presented. Results: The elderly group had lower accuracy and slower reaction time than the young group. There were significant interactions between the group and time-window. The young group fixated the target longer than the elderly group in the time window of $1,000-1,800 \mathrm{~ms}$. According to the proportion data of the interference type, there were significant interactions between types and time-window. Both groups fixated the phonologically related picture longer than semantically related picture or unrelated picture in 1,0001,400 ms time-window. Conclusion: Elderly adults demonstrated delayed processing when compared with younger adults, whereas age-group differences did not emerge as a function of the interference types. There was aging-related decline in online processing of the word recognition abilities, but differential effects by the interference types did not efficiently discriminate the groups, indicating that their online processing abilities to inhibit phonologically and semantically related foils may be intact, although elderly adults suffered from slowed processing.
\end{abstract}

Keywords: Word recognition, Eye-tracking, Proportion of fixation, Aging
노화에 따라 노인은 생물학적 기능의 저하와 더불어 전반적인 감 각 및 지각능력의 감퇴를 경험한다(Akutsu, Legge, Ross, \& Schuebel, 1991; Faubert, 2002). 이로 인해 노인들에게 인지적인 측면에서 어떠 한 변화가 일어나게 되는지 연구하는 것은 노인들의 정신활동을 이 해하는 데 매우 중요하다. 지각, 기억, 학습 등 인지의 다각적인 측면 에서 노화에 따른 감퇴는 널리 인정되고 있지만(Craik, 2017; Craik \& Byrd, 1982; Faubert, 2002; Humes \& Floyd, 2005; Jeong, 2004; Ko \& Kwon, 2006; Lee, 2003; Madden et al., 2002; Park \& Jin, 2002; Park, 2004; Salthouse, 2004), 언어처리 측면에서는 노화의 영향에
관해 연구에 따라 상반된 결론을 주장하고 있다. 언어처리 능력은 노화에 따른 변화에 비교적 안정적이며, 특히 어휘와 관련된 지식 의 저장 및 조직 부분은 오히려 나이가 들어감에 따라서 능력이 점 차 증가한다는 주장이 있다(Burke \& Peters, 1986; Jeong \& Pyun, 2005; Lovelace \& Cooley, 1982; Park et al., 2002; Scialfa \& Margolis, 1986; Spieler \& Balota, 2000). 반면, 노화로 인해 단어재인 속도나 읽 기 속도가 저하됨을 보고하는 결과도 다수 존재한다(Balota \& Duchek, 1988; Howard, Shaw, \& Heisey, 1986; Sass, Legge, \& Lee, 2006; Speranza, Daneman, \& Schneider, 2000). 본 연구에서는 언어 
처리 능력 중 음운론적, 의미론적 측면에서 노화에 따른 손상이 있 는지 단어재인 과제를 시선추적기법을 활용해 살펴보았다.

먼저, 음운론적 언어능력과 관련하여 노인들이 크게 어려움을 느끼는 대표적인 문제로 설단현상(tip-of-the-tongue phenomenon) 이 있다(Rayner \& Sereno, 1994). 설단현상은 이미 기존에 알고 있 는 단어의 이름을 산출하려고 할 때 일시적으로 말문이 막히는 현 상이다(Brown \& McNeill, 1966). 설단현상을 경험하는 동안 목표 어휘에 대한 문법적인 정보나 의미적인 정보를 산출하는 것은 가능 하지만, 음운적 정보에 있어서 전부 또는 부분적으로 떠오르지 않 는다(Brown \& McNeill, 1966; Brown, 1991; Caramazza \& Miozzo, 1997). 즉, 이러한 현상의 원인 중 하나는 노인들이 청년들에 비해 단어 산출을 위한 음운적 정보 전달을 위한 연결이 약화되면서 청 년에 비해 불충분한 음운적 정보를 사용하기 때문이라고 보았다 (Burke, Mackay, Worthley, \& Wade, 1991; Cohen \& Faulkner, 1986; Maylor, 1990).

노인의 설단현상에 대해 국내외에서 많은 연구가 보고되고 있다. 실제로 일상생활에서 일정기간 동안 설단현상의 발생을 기록하게 하였을 때, 노년층은 청년층에 비해 더 많은 설단현상을 보고하였 다. Burke 등(1991)의 연구에서는 노년층이 청년층에 비해 2.7번, Cohen과 Faulkner (1986)의 연구에서는 노년층이 청년층과 비교 하여 2.0 번, 중년층과 비교하여 2.4번 더 많은 빈도를 기록하였다. 그러나 Heine, Ober와 Shenaut (1999)는 청년층과 60-74세의 노년 층 간에 큰 차이가 없었고, 80 세 이상의 노년층에서만 청년층과 비 교하여 설단현상이 유의하게 증가한 것을 관찰하였다.

연령의 차이에 따라 설단현상의 발생빈도에 차이가 나타나기도 하지만, 단어의 범주에 따라 차이의 정도는 달라질 수 있다. 설단현 상에서의 연령차이는 보통명사(common noun)에 비해 고유명사 (proper noun)에서 두드러지게 나타난다(Burke et al., 1991; Evrard, 2002; Rastle \& Burke, 1996). 고유명사 중 특히 인물이름에서는 노 년층이 청년층보다 설단현상이 더 빈번하게 발생된다고 보고되었 지만(Cross \& Burke, 2004; Evrard, 2002), 장소이름에서는 연령차 가 나타나지 않기도 한다(Burke et al., 1991). 보통명사의 경우 일반 적으로 연령차가 나타나지 않지만(Burke et al., 1991; Evrard, 2002), 80세 이상의 노년층에서는 청년층에 비해 더 많은 설단현상이 관 찰되기도 한다(Heine et al., 1999). 보통명사 중 사물이름을 자극으 로 주로 사용한 Brown과 $\mathrm{Nix}$ (1996)의 연구에서 60세 이상의 노인 층에서도 연령에 의한 차이가 관찰되었다. 국내 연구로 Park, Lee와 Lee (2013)는 청년층과 노년층을 대상으로 설단현상의 발생 및 해 결에 관해 보고하였다. 그 결과, 청년층보다 노년층에서 더 많은 설 단현상이 발생하며, 범주에 따라 설단현상의 발생에 있어 차이가
있음을 보고하였다. 설단현상은 인물, 장소와 같은 고유명사에서 자주 발생하였으며, 청년층과 노년층 모두 재인에 비해 회상을 통 한 해결을 주로 보였고, 수행력의 차이는 노년층에서 더 크게 나타 났다. Oh (2015)는 청년층, 장년층, 중년층, 노년층과 경도인지장애 (mild cognitive impairment) 그룹을 대상으로 유명인 이름대기 과 제를 실시하였다. 그 결과, 정상적 노화 과정에서 연령 증가에 따라 설단현상이 더 많이 발생함을 확인할 수 있었으나, 단서 제시에 따 른 설단현상의 해결 측면에서는 오히려 감소하는 양상을 보였다. 그 러나 실험에 참여한 각 집단별 대상자의 수가 한정적이었으며, 설단 현상의 해결을 유도하기 위해 주어지는 첫음절 또는 끝음절 단서가 집단에 따라 구분되었기 때문에 각 단서의 영향을 직접적으로 비 교하기에는 어려움이 있었다.

다음으로 노화에 따른 가장 두드러진 언어능력의 손상이 의미 론적 측면이라고 주장하는 연구들이 있다. 의미론적 측면의 언어 능력을 살펴볼 수 있는 대표적인 과제로 단어인출결함과 관련된 단 어 이름대기 과제와 단어정의하기 과제가 있다. 단어인출결함은 Levelt, Roelofs와 Meyer (1999)의 어휘산출모델을 기반으로 하는 데, 이 모델은 어휘의 개념을 형성하는 개념화 단계, 의미표제어 선 택 단계, 음운적으로 부호화되는 단계로 나뉜다. 개념화 단계의 손 상은 치매 등 인지장애 환자에게 주로 나타나며(Lambon Ralph, Sage, \& Roberts, 2000), 의미표제어 선택은 정상적으로 수행되었 고, 음운부호화 단계에 실패한 경우에는 설단현상으로 간주한다 (Brown, 1991). 의미표제어 선택의 단계 단독으로 결함이 발생한 경우, 의미론적 언어능력의 손상되어 단어인출이 어려워지고, 그 로 인해 이름대기 능력이 감소한다고 보았다(Hough, 2007; Kaplan, Goodglass, \& Weintraub, 1983; Zec, Markwell, Burkett, \& Larsen, 2005). 또한 이러한 능력감소로 인해 담화를 산출함에 있어 주제의 일관성과 응집 정도가 떨어지게 된다(Cooper, 1990; Glosser \& Deser, 1992; Koo \& Choi, 2015).

단어 이름대기 과제에서 젊은 연령층에 비해 노년층이 정확성과 유창성이 감소하고 느린 반응을 보인다는 점은 많은 연구에서 보고 하고 있다(Feyereisen, 1997; Nicholas, Barth, Obler, Au, \& Albert, 1997; Ramsay, Nicholas, Au, Obler, \& Albert, 1999; SchmitterEdgecombe, Vesneski, \& Jones, 2000). 이름대기 과제는 주로 대면 이름대기(confrontation naming)검사 및 통제낱말연상검사(Controlled Oral Word Association Test, COWAT)를 활용하는데, 그중 보스턴이름대기검사(Boston Naming Test, BNT; Kaplan et al., 1983)는 대표적인 대면이름대기 과제이다. 보스턴이름대기검사를 활용하여 건강한 성인들을 대상으로 실시한 연구결과에 따르면, 청년층에 비해 노년층의 이름대기 수가 적었다(Ramsay et al., 1999). 
건강한 성인 남성과 여성을 대상(30-79세)으로 한 Nicholas, Obler, Albert와 Goodglass (1985)의 연구에서도 연령 증가에 따라 이름대 기 수가 감소하는 경향을 보였다. 또한 54-75세의 정상 장년층과 노 년층을 대상으로 이름대기를 실시한 Hough (2007)의 연구에서 전 체 대상자의 $28 \%$ 가 정상범주에서 벗어난 수행력을 보였는데, 이는 연령에 따른 인지적 처리 능력이 제한된 결과, 어휘 및 의미적 속성 을 반영하는 이름대기 능력의 저하를 초래하였다고 보았다.

단어정의하기 과제는 제시된 단어의 개념을 설명하는 과제로, 단 어정의를 하기 위해서는 그 단어에 관한 의미지식(semantic knowledge)과 그 지식을 적절하게 표현하기 위한 어휘목록(lexicon)을 갖 고 있어야 한다. 또한 그것을 적절하게 표현할 수 있는 구문능력과 '정의하기'에 대한 상위언어적 지식(metalinguistic knowledge)이 요구된다(Snow, 1990). Bowles와 Poon (1985)은 청년층 18명과 노 년층 18 명에게 단어정의를 들려주고, 들은 정의에 해당하는 단어 가 무엇인지 말하도록 하였다. 그 결과, 노년층은 청년층에 비해 정 반응한 문항의 수가 적고 반응시간도 비교적 지연되었다. 국내에서 는 Kim과 Choi (2012)가 65세 이상 41명의 노년층과 20-30대 50명 의 청년층을 대상으로 단어정의하기 과제를 실시한 결과, 노년층의 정의 점수는 청년층보다 유의하게 낮았다.

반면, 정상 노년층 언어능력의 의미적 측면에 대한 상반된 견해 도 존재한다. 의미처리 측면에서 노인은 청년과 비슷하거나 또는 더 나은 수준의 수행을 보인다는 연구도 있다(Kim \& Lee, 2007; Lee, Kim, Lee, Jung, \& Park, 2012; Wingfield \& Stine-Morrow, 2000; Verhaeghen, 2003). 먼저, 단어 이해와 같은 측면에서 살펴보면, 정 상 노년층의 단어를 이해하거나, 사실적 의미에 관한 이해는 청년 층과 크게 다르지 않다고 보는 견해가 일반적이다(Bayles, Tomoeda, Kaszniak, Stern, \& Eagans, 1985; Belmore, 1981; Cohen, 1979). 또한 노인들은 글 이해에서 맥락을 잘 활용하고(Wingfield \& StineMorrow, 2000), 청년보다 높은 어휘력 점수를 보였다(Verhaeghen, 2003). 나이가 증가하면서 일반적 상식도 증가하는 것 또한 의미적 표상이 증가하는 증거로 볼 수 있다(Beier \& Ackerman, 2001). 이 름대기 과제에서도 연령이나 과제 유형 등에 따라 결과에 차이가 발생하며, 70 세 이상의 노년층에게서만 이름대기 장애가 관찰된다 는 보고도 있다(Feyereisen, 1997). 그 외, 정의하기 능력 또한 노인 이 되어도 보존된다고 보고한 연구결과(Bowles \& Poon, 1985; Fox, 1947; Gordon \& Kindred, 2011)가 있다.

노년층의 언어처리 능력과 관련하여 기존에 많이 사용된 연구방 법은 피험자에게 제시된 자극을 읽고 이해한 후, 말하기나 쓰기를 통해 산출된 반응에서 수행의 정반응률이나 반응시간을 측정하 는 것이었다. 이러한 과제들은 절차상 반응 산출을 위한 부수적인
운동기능의 계획 및 실행 등이 관여한다는 점에서 순수한 언어처 리 과정을 알아보기에는 제약이 있다. 또한 이러한 방법은 과제 수 행의 결과는 확인할 수 있지만, 과제를 수행하는 동안 어떠한 언어 처리과정(language processing)이 일어나는지에 대한 실시간 정보 를 제공하지 않는다. 반면, 시선추적기법은 비침습적이며, 실험자 극의 다양한 조작이 가능하여 최대한 자연스러운 언어처리 과정을 실시간으로 관찰할 수 있다는 이점이 있다. 또한 언어처리 과정에 대한 객관적이고, 정량적인 정보를 제공해 준다(Cooper, 1974). 시 선추적기법의 이러한 장점에 기반하여 노년층의 언어능력과 관련 한 연구가 점차 증가하는 추세이다.

언어처리에 관련한 시선추적연구 중 청각적, 시각적 자극을 제시 하고 시선을 추적하여 어휘 현상(lexical phenomena)을 알아보는 방법이 있다. 이러한 연구방법에서는 주로 목표자극과 함께 방해 자극이 제시되는데, 여기서 방해자극이란 청각자극에 해당하는 목표어휘를 선택하는 과정에서 간섭을 일으키게 되는 자극이다. 방해자극은 연구에 따라 목표어휘와 관련 없는 단어만 포함되기 도 하고, 음운론적으로 관련된 단어 또는 의미론적으로 관련된 단 어가 모두 포함되기도 한다. 방해자극이 포함된 과제의 수행결과 를 통해, 어휘처리 과정에서 해당 능력의 손상이 있는지 세부적인 측면을 확인할 수 있다(Yee, Blumstein, \& Sedivy, 2008). 예를 들어 Cooper (1974)는 그림자극과 청각자극이 제시되었을 때, 목표어의 일부분 또는 전부를 듣고, 관련이 없는 방해자극에 비해 목표자극 을 더 응시한다고 처음으로 제시하였다. Tanenhaus, Magnuson, Dahan과 Chambers (2000)는 4개의 그림 중에서 청각적으로 제시 된 목표자극을 고르는 과제를 진행하였고, 그 결과 음운론적으로 관련 없는 단어에 비해 음운론적으로 관련 있는 단어를 더 많이 고 정하는 것으로 보고하였다. Ben-David 등(2011)은 실험환경을 조 용함과 소음 상황으로 구분하고, 음운적으로 유사한 단어를 시작 (onset)이 유사한 단어군(예: tower-towel)과 단어의 끝(rhyme)이 유사한 단어군(예: house-mouse)으로 구분하여 진행하였다. 결과 적으로 어떠한 조건에서도 청년층과 노년층 간의 정확도에서 차이 가 없었다. 또한, 조용한 상황에서도 두 집단 간 유의한 차이가 확인 되지 않았다. 반면, 소음 내 환경에서는 노년층이 끝소리가 유사한 단어와 목표자극을 구분하는 데 시간이 지연되고, 유의미한 어려 움이 있다는 것을 확인할 수 있었다. Yee와 Sedivy (2001)는 구어 인 식(spoken word recognition) 시 의미정보의 활성화를 알아보기 위 해 연구를 진행하였다. 그 결과 목표어휘의 청각자극을 듣고, 목표 어휘와 의미적으로 관련된 단어(예: lock-key)를 무관련 어휘보다 더 많이 응시하는 것을 알 수 있었다. Yee 등(2008)은 참여자 범위 를 확대하여 정상 청년층과 노년층 이외에 추가적으로 브로카 실 
어증 환자와 베르니케 실어증 환자까지 포함하였고, 세부실험은 각 3 회에 걸쳐 이루어졌다. 그 결과 노년층은 청년층과 유사하게 무관 련 어휘에 비해 의미적으로 관련된 어휘(예: cherry-banana), 목표 어와 음소적 시작점이 같은 어휘(예: hammer-hammock), 목표어 와 의미적으로 관련된 어휘의 음운적 경쟁 어휘(예: hammock $\rightarrow$ hammer $\rightarrow$ nail)에 시선을 고정하는 것으로 나타났다. 이러한 결과 를 통해 의미적, 음운적 정보의 활성화양상에 관하여 확인할 수 있 었다. 위의 연구들을 종합해 보면, 단어재인 과제의 수행을 시선추 적기법을 활용하여 살펴보는 것은 노화로 인한 언어처리 특성을 구 체적으로 알아보는 데 효과적인 연구방법인 것을 알 수 있다. 아직 국내에서는 시선추적기법을 통해 노화에 따른 단어재인 능력을 관 찰한 사례가 드물다. 시선추적기법을 활발하게 적용하고 있는 분 야는 읽기장애 부분으로 아동과 언어장애군을 대상으로 한 연구 가 주로 이루어지고 있다(Choi \& Koh, 2009; Kang \& Yim, 2018; Kim \& Koh, 2007; Koh \& Yoon, 2007; Koh, Hong, Yoon, \& Cho, 2008; Koh et al., 2010).

본 연구에서는 선행연구인 Yee 등(2008)의 실험을 참고하여 청 각자극과 함께 목표어휘의 그림자극, 목표자극과 음운적, 의미적 으로 유사한 그림자극, 목표자극과 관련이 없는 그림자극을 제시 한 후, 청각자극에 해당하는 그림을 찾아 버튼을 눌러 응답하는 방 식으로 단어재인 과제를 진행하였다. 본 연구를 통해 노화로 인한 전반적인 감각 및 지각 능력의 저하가 단어재인 과제를 수행함에 있어 청년층과 비교하여 정확도 및 반응속도에서 차이를 보이는지, 그리고 목표어휘와 함께 제시된 방해자극의 유형(음운적 유사성, 의미적 유사성, 무관련)에 의해 영향을 받는지 시선추적기법을 통 해 알아보고자 하였다. 구체적인 연구 질문은 아래와 같다.

첫째, 단어재인 과제에서 청년층과 노년층 간 정반응률 및 반응 시간에 유의한차이가 있는가?

둘째, 단어재인 과제의 목표자극 시선고정비율(proportion of fixation)에서 구간에 따라 집단(청년층 vs. 노년층) 간 차이가 유의 한가?

셋째, 단어재인 과제의 방해자극 시선고정비율(proportion of fixation)에서 구간에 따라 집단(청년층 vs. 노년층) 간 차이가 유의 한가?

\section{연구방법}

\section{연구대상}

본 연구는 정상 청년층 30 명과 정상 노년층 30 명을 대상으로 하 였다. 두 집단은 모두 (1) 한국어를 모국어로 사용하며, (2) 교육년수
Table 1. Descriptive information on participants

\begin{tabular}{lccc}
\hline & $\begin{array}{c}\text { Normal young } \\
\text { group (N=24) }\end{array}$ & $\begin{array}{c}\text { Normal elderly } \\
\text { group (N=22) }\end{array}$ & $t$ \\
\hline Age (yr) & $21.17(1.49)$ & $68.95(5.23)$ & - \\
Education (yr) & $12.73(1.08)$ & $11.63(2.57)$ & 1.85 \\
\hline
\end{tabular}

Values are presented as average (SD).

가 6년 이상이며, (3) 서울 및 경기도에 거주하며, (4) 한국형 간이정 신상태검사(Korean-Mini Mental State Examination, K-MMSE; Kang, Na, \& Hahn, 1997) 점수가 연령 및 교육년수에 비해 $16 \%$ ile 이상으로 정상 범위에 해당하는 자(Kang, 2006), (5) 시력과 청력에 이상이 없고, (6) 자가보고를 통해 폐쇄공포증이 없음을 밝혔으며, (7) Christensen, Multhaup, Nordstrom과 Voss (1991)의 건강선별 설문지(Health Screening Questionnaire)를 실시하여 신경학적 손 상 및 정신적 병력이 보고되지 않은 자를 선정하였다. 추가적으로 노년층에게는 언어기억검사(Seoul Verbal Learning Test, SVLT; Kang \& Na, 2003)를 진행하여, 각 점수가 연령 및 교육년수에 비해 $16 \%$ ile 이상으로 정상 범위에 해당하는 자를 대상으로 선정하였다 (Kang, Jahng, \& Na, 2012). 선정된 이들을 대상으로 실험을 진행한 후, 평균과 표준편차를 계산하여 $\pm 3 \mathrm{SD}$ 범위를 벗어나는 값은 이 상값(outlier)으로 처리하여 분석에서 제외하였다. 또한, 시선보정 (calibration) 및 검증(validation)에서 동공의 X축, $\mathrm{Y}$ 축의 편차(eye deviation)가 불안정한 값을 제외하여 청년층 24 명과 노년층 22 명, 총 46 명의 자료를 최종적으로 분석에 사용하였다. 본 연구에 참여 한 집단별 대상자 정보는 Table 1에 제시하였다. 집단별 교육년수에 유의한 차이가 있는지 알아보기 위하여 독립표본 $t$-검정(independent samples $t$-test)을 실시하였다. 그 결과, 두 집단 간 교육년수는 통계적으로 유의한 차이가 없는 것으로 나타났다 $\left(t_{(27.71)}=1.85\right.$, $p>$.05).

\section{실험 자극}

실험 자극은 기본적으로 Yee 등(2008)의 실험 과제를 참고 및 수 정하여 목표어휘 20 개, 음운적 관련 어휘 20 개, 의미적 관련 어휘 20 개, 목표어휘와 음운적, 의미적으로 관련 없는 무관련 어휘 20 개 를 선정하였다. Nam 등(1997)은 음절의 길이에 따라 수행력에서 차이가 발생한다고 보고하였으므로, Lee (2001)의 연구결과에 따 라 우리말 어휘 중 빈도가 가장 높다고 보고한 2,3음절로 구성하였 다. 또한 과제 수행에서 단어의 품사에 따른 영향을 배제하기 위해 모두 명사형으로 선정하였다. 또한 고유명사 및 추상명사를 제외한 구체 명사만 선택하였으며, 범주와 첫음절의 초성값을 고려하여 선 정하였다. 범주는 일차적으로 선행연구인 Yee 등(2008)의 실험자 
Table 2. Examples of stimuli for each category

\begin{tabular}{lcccc}
\hline Category & Target & $\begin{array}{c}\text { Phonological } \\
\text { competitor }\end{array}$ & $\begin{array}{c}\text { Semantic } \\
\text { competitor }\end{array}$ & $\begin{array}{c}\text { Unrelated } \\
\text { competitor }\end{array}$ \\
\hline Animal & $\begin{array}{c}\text { spider } \\
\text { (geo-mi) }\end{array}$ & $\begin{array}{c}\text { mirror } \\
\text { (geo-ul) }\end{array}$ & $\begin{array}{c}\text { ladybug (mu- } \\
\text { dang-beol-rae) }\end{array}$ & $\begin{array}{c}\text { piano } \\
\text { (piano) }\end{array}$ \\
$\begin{array}{c}\text { Fruit \& vegeta- } \\
\text { ble }\end{array}$ & garlic & carriage & carrot & chick \\
(ma-neul) & (ma-cha) & (dan-geun) & (byeong-a-ri) \\
Miscellaneous & umbrella & milk & rubber boots & seesaw \\
goods & (u-san) & (u-yu) & (jang-hwa) & (si-so) \\
Transportation & bus & mushroom & car & calculator \\
& (bus) & (beo-seot) & (cha) & (gye-san-gi) \\
Stationary & eraser & stick & scissors & eagle \\
& (ji-u-gye) & (ji-pang-i) & (ga-wi) & (dok-su-ri) \\
\hline
\end{tabular}

극을 참고하였으며, 우리말 어휘로 자극을 구성하기 위해 Park, Sung과 Sim (2014)의 범주판단 과제에 사용된 범주 구분을 참고하 였다. 그 결과, 동물, 과채류, 잡화, 교통수단, 학용품의 5 개 범주가 선정되었고, 목표자극은 각 범주당 4 개의 어휘로, 총 20 개이다. 실 험에서 사용한 자극의 예시는 Table 2 및 Figure 1과 같다. 실험자극 전체 목록은 Appendix 1에 제시하였다.

\section{연구 도구}

본 연구는 시선추적기(Eye-Tracker)를 활용하여 데이터를 수집 하였다. 시선추적기는 적외선 조명과 컴퓨터 기반의 이미지 프로세 싱을 사용하여 안구의 위치와 움직임을 실시간으로 추적하여 인지 과정을 확인할 수 있다. 즉, 장비에 설치된 카메라가 피험자의 눈에 적외선을 투사하여 피험자의 각막에서 반사된 빛인 각막광(corneal glint)으로 안구의 움직임을 추적하는 것이다(Jang, 2012). 우리 의 눈은 관심이 있는 대상에 초점을 맞추기 위해 동공을 움직인다. 이러한 동공의 움직임을 추적하면 응시방향을 통해 “무엇을", "얼 마 동안", “어떻게” 바라보고 있는가에 대한 정보를 정량적으로 알 아낼 수 있다. 본 연구에서 사용한 시선추적 측정방법은 Remote Eye-tracking Device (RED)방식으로, Senso Motoric Instrument (SMI)사의 RED 500으로 측정하였다. RED방식은 소형 카메라가 사람의 눈과 시야를 촬영하여, 양상을 통해 눈동자의 위치나 반사 광의 위치를 파악하여 안구의 방향 즉, 시선을 측정하게 된다. 단, 사용자가 머리를 움직이면 카메라 초점이 안구의 위치를 벗어나게 되므로, 정확한 측정이 불가능하게 된다. 이러한 점을 보완하기 위 해 본 실험 시 턱고정대(chin rest)를 활용하여 피험자의 머리 흔들 림을 방지하였다.

\section{연구 절차}

모든 피험자에게 개별적으로 실시되었으며, 소음 요인을 배제하

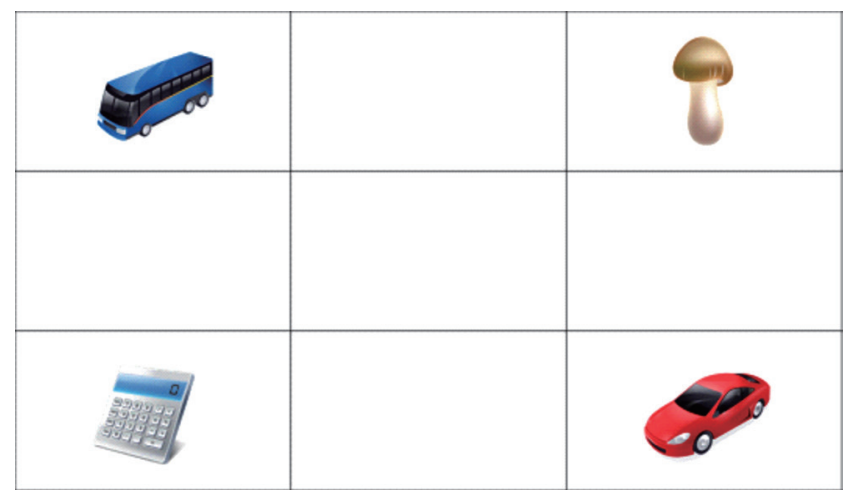

Figure 1. A sample display from experiment. The target object, (bus/bus), is semantically related to one of the other objects (the semantic competitor, car/ cha) and phonologically related to one of the other objects (the phonological competitor, mushroom/beo-seot) in the display. The other object is unrelated semantically and phonologically to the target (unrelated competitor, calculator/gye-san-gi).

기 위해 조용한 공간에서 진행되었다. 참가자와 모니터 사이의 거리 는 60-70 cm로 실험자극은 흰색 바탕에 색이 들어간 그림으로 제 시되었다. 그림은 구글(Google)과 아이클릭아트(Iclickart)에서 이 미지 검색을 통해 1 차적으로 선별한 후, 전문가에게 맡겨 크기, 선명 도, 밝기, 대비 등을 2 차적으로 조정하였다. 모니터는 $1,920 \times 1,080$ 해상도로, 그림은 $3 \times 3$ 열로 각각의 코너에 제시되었다. 정답 위치 는 각 코너에 빈도수가 동일하게 배열하였다. 연구자는 본 실험의 시작에 앞서 시선추적 장치와 연구 전반에 대하여 간략히 안내하 였다. 자리에 착석하고, 머리 움직임을 최소화하기 위하여 턱과 이 마를 받침대에 고정하면 화면에 순서대로 제시되는 점 9 개를 차례 대로 응시하도록 함으로써 안구의 위치를 정위(calibration)하는 절 차를 거쳤다. 이 과정은 추적되는 안구 위치와 모니터상의 응시점 들이 대응을 이루도록 하는 데 필요한 것이다. 응시점과 안구의 위 치를 계산한 결과, $0.5^{\circ}$ 이내일 때 유효한 측정이 가능한 값으로 간 주하였다(Holmqvist et al., 2011). 기록의 정확성과 신뢰성을 위해 위 과정은 실험 과정 중 15 문항 간격으로 총 4 회 실시하였다. 정위 및 확인 절차가 완료되면 연습 시행을 실시하여 참여 대상자가 과 제 수행 방법을 완벽하게 익힐 수 있도록 하였다. 연습문항은 본 문 항과 동일한 방식으로 총 10 문항을 무작위로 배열하여 제시하였 다. 연구자는 대상자의 반응을 확인하면서 피드백을 주었고, 대상 자가 과제를 쉽게 이해할 수 있도록 설명을 제공한 후에 본 과제를 실시하였다. 필요한 경우에는 연습 시행을 반복하여 본 시행에 앞 서 과제 수행 방법을 완벽히 숙지할 수 있도록 하였다. 본 실험의 각 문항들은 화면 중앙에 응시점 '+' 표시가 나타나면서 시작된다. 응 시점이 나타났다가 2 초 후 사라진 뒤 이어서 목표어휘의 청각적 자 


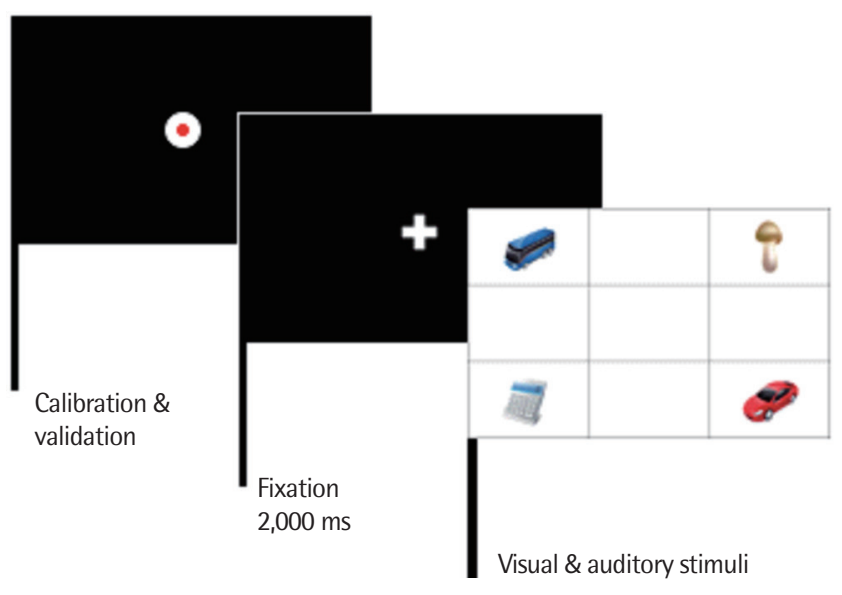

Figure 2. Experimental procedures.

극과 목표어휘, 음운적 관련 어휘, 의미적으로 관련된 어휘, 무관련 어휘가 포함된 그림자극이 제시된다. 연구자는 대상자에게 청각적 자극이 제시된 후, 4 개의 그림 중 청각적 자극에 해당하는 그림을 골라 키보드를 누르라고 지시하였다. 목표자극 20 문항과 메꿈질 자극(Filler stimuli) 40 문항, 총 60 문항으로 구성되어 있으며, 본 실 험 과제의 소요시간은 약 10 분이다. 선별검사를 포함한 전체 소요 시간은 1 시간에서 1 시간 15 분 정도 소요되었다. 본 실험 과제의 순 서도는 Figure 2와 같다.

\section{자료 분석}

\section{정반응률}

피험자가 4 개의 그림 중 청각적 자극과 동일한 그림을 고른 경우 1 점, 오반응 한 경우 0 점으로 계산한다. 정반응률(\%)은 정반응한 문항수를 전체 문항수인 20으로 나눈 후 100 을 곱하여 계산하였다.

정반응률 $(\%)=($ 정반응한 문항수 $/$ 전체 문항수 $) \times 100$

\section{반응시간}

청각적 자극과 그림자극이 제시된 순간부터 실험 대상자가 청각 적 자극에 해당하는 그림자극을 고른 뒤, 키보드를 눌러 선택한 시 간까지를 측정하였다. 밀리세컨드 $(\mathrm{ms})$ 단위로 측정하였으며, 반응 시간은 피험자가 정반응한 문항들에 대해서만 분석되었다. 또한 반응시간의 평균과 표준편차를 계산하여 $\pm 3 \mathrm{SD}$ 범위를 벗어나 는 값은 이상값(outlier)으로 처리하여 분석에서 제외하였다.

\section{목표자극의 시선고정비율}

화면에 제시된 4 개의 그림자극 중 청각적 자극과 일치하는 목표 자극의 그림을 본 시간의 비율이다. 제시된 자극 중 목표자극을 응
시한 시선고정비율을 구하기 위해 목표자극의 시선고정기간(total fixation duration)을 목표자극과 3 개의 방해자극의 시선고정기간 을 더한 값으로 나누어 계산하였다.

$$
\text { 목표자극의 시선고정비율 = 목표자극의 시선고정기간/ }
$$

총시선고정기간(목표자극+방해자극)

\section{방해자극의 시선고정비율}

화면에 제시된 4 개의 그림자극 중 청각적 자극과 일치하지 않는 그림자극을 본 시간의 비율이다. 방해자극의 시선고정비율은 유형 별(음운유사, 의미유사, 무관련)로 각각 계산하였다. 예를 들어 음 운유사 어휘의 시선고정비율을 구하기 위해 음운유사 그림자극의 시선고정기간(total fixation duration)을 3 개의 방해자극(음운유 사, 의미유사, 무관련)의 시선고정기간을 더한 값으로 나누어 계산 하였다.

각 방해자극별 시선고정비율 =각 방해자극의 시선고정기간/

방해자극 시선고정기간(음운유사+의미유사+무관련)

\section{자료의 전처리 과정(Data Preprocessing Procedure)}

시선추적 데이터를 SMI사의 BeGaze 3.7과 Microsoft사의 Excel 2017 프로그램을 이용하여 분석하였다. 추출과정에서 선행연구 (Amso, Haas, \& Markant, 2014)에 따라 시선보정(calibration) 및 검증(validation)을 실시하였을 때, 동공의 X축, $\mathrm{Y}$ 축의 편차(eye deviation)가 불안정한 값은 시선고정비율 분석에서 제외하였다. 또한 표준편차(SD)를 구하여 $\pm 3 \mathrm{SD}$ 범위를 벗어나는 값은 이상값(outlier)으로 처리하여 분석에서 제외하였다. 본 실험에서 정반응한 문 항들만 선택한 후, 각 개별 데이터를 $100 \mathrm{~ms}$ 단위로 추출하였다. 분 석구간은 선행연구인 Yee 등(2008)의 실험을 참고 및 수정하여 자 극 제시 후 $200 \mathrm{~ms}$ 부터 $400 \mathrm{~ms}$ 간격으로 2,600 ms까지 6개의 구간 으로 설정하였다.

\section{자료의 통계적 처리}

통계적 처리를 위해 SPSS 23.0 을 사용하였다. (1) 단어재인 과제 에서 청년층과 노년층 간 정반응률 및 반응시간에 유의한 차이가 있는지 알아보기 위해 독립표본 $t$-검정을 실시하였다. (2) 단어재인 과제에서 목표자극의 시선고정비율이 구간에 따라 청년층과 노년 층간 유의한차이가 있는지 알아보기 위해 이원혼합분산분석(twoway mixed ANOVA)을 실시하였다. (3) 단어재인 과제에서 방해자 극(의미유사, 음운유사, 무관련)의 시선고정비율이 구간에 따라 청 년층과 노년층 간 유의한 차이가 있는지 알아보기 위해 삼원혼합 분산분석(three-way mixed ANOVA)을 실시하였다. 


\section{타당도}

실험 자극의 타당도를 알아보기 위해 본 실험에 참여하지 않은 언어병리학과 대학원생 20명을 대상으로 실험자극에 대한 타당도 검사를 실시하였다. 타당도검사는 실험에 사용할 그림자극을 제시 하고, 그에 해당하는 이름을 적는 방식으로 진행하였다. 설문지는 구글(Google) 드라이브 내 설문지 만들기를 활용하였으며, 설문조 사 참여자들이 사이트에 접속하여 설문지를 작성하였다. 검사 결 과를 토대로 $90 \%$ 이상 동일하게 응답한 그림자극만 사용하였다.

\section{연구결과}

\section{정반응률}

단어재인 과제에서 집단(청년층 vs. 노년층) 간 정반응률의 차이 를 알아보기 위해, 독립표본 $t$-검정을 실시하였다. 기술통계 결과는 Table 3 과 같다.

기술통계 결과, 두 집단 간차이가 통계적으로 유의하였다 $\left(t_{(24.76)}=\right.$ $2.75, p<.05$ ) 노년층(평균 96.82\%)은 청년층(평균 99.58\%)에 비해

Table 3. Descriptive data of accuracy rate on word recognition tasks

\begin{tabular}{lccc}
\hline & $\begin{array}{c}\text { Normal young group } \\
(\mathrm{N}=24)\end{array}$ & $\begin{array}{c}\text { Normal elderly group } \\
(\mathrm{N}=22)\end{array}$ & $t$ \\
\hline Accuracy $(\%)$ & $99.58(1.41)$ & $96.82(4.51)$ & 2.75 \\
\hline
\end{tabular}

Values are presented as mean (SD).

Table 4. Descriptive data of reaction time on word recognition tasks

\begin{tabular}{lccc}
\hline & $\begin{array}{c}\text { Normal young group } \\
(\mathrm{N}=24)\end{array}$ & $\begin{array}{c}\text { Normal elderly group } \\
(\mathrm{N}=22)\end{array}$ & $t$ \\
\hline Reaction time $(\mathrm{ms})$ & $1,892.18(229.85)$ & $2,703.14(434.36)$ & -8.01 \\
\hline
\end{tabular}

Values are presented as mean (SD).
유의하게 낮은 정반응률을 보였다.

\section{반응시간}

단어재인 과제에서 집단(청년층 vs. 노년층) 간 반응시간의 차이 를 알아보기 위해, 독립표본 $t$-검정을 실시하였다. 기술통계 결과는 Table 4 와같다.

기술통계 결과, 두 집단 간 차이가 통계적으로 유의하였다 $\left(t_{(44)}=\right.$ $-8.01, p<.05$ ). 노년층(평균 $2,703.14 \mathrm{~ms}$ )은 청년층(평균 $1,892.18 \mathrm{~ms}$ ) 에 비해 유의하게 반응시간이 느렸다.

\section{목표자극의 시선고정비율}

단어재인 과제에서 목표자극의 시선고정비율의 집단 간 차이를 알아보기 위해, 청년층과 노년층을 집단 간 요인으로, 6 개의 구간 (200-600 ms, 600-1,000 ms, 1,000-1,400 ms, 1,400-1,800 ms, 1,800$2,200 \mathrm{~ms}, 2,200-2,600 \mathrm{~ms})$ 을 집단 내 요인으로 하여 목표자극의 시선고정비율을 종속변수로 한 이원혼합분산분석을 실시하였다. 구간에 따른 두 집단의 목표자극의 시선고정비율의 평균과 표준편 차는 Table 5에 제시하였으며, Figure 3에는 평균과 표준오차를 제 시하였다.

Table 5. Descriptive data of proportion of fixations over time to the target

\begin{tabular}{lcc}
\hline & $\begin{array}{c}\text { Normal young group } \\
(\mathrm{N}=24)\end{array}$ & $\begin{array}{c}\text { Normal elderly group } \\
(\mathrm{N}=22)\end{array}$ \\
\hline Phase $1(200-600 \mathrm{~ms})$ & $.45(.29)$ & $.41(.21)$ \\
Phase $2(600-1,000 \mathrm{~ms})$ & $.46(.34)$ & $.38(.22)$ \\
Phase $3(1,000-1,400 \mathrm{~ms})$ & $1.04(.40)$ & $.53(.40)$ \\
Phase 4 $(1,400-1,800 \mathrm{~ms})$ & $1.60(.63)$ & $.84(.62)$ \\
Phase $5(1,800-2,200 \mathrm{~ms})$ & $1.13(.77)$ & $.99(.72)$ \\
Phase $6(2,200-2,600 \mathrm{~ms})$ & $.47(.48)$ & $.78(.65)$ \\
\hline
\end{tabular}

Values are presented as mean (SD).

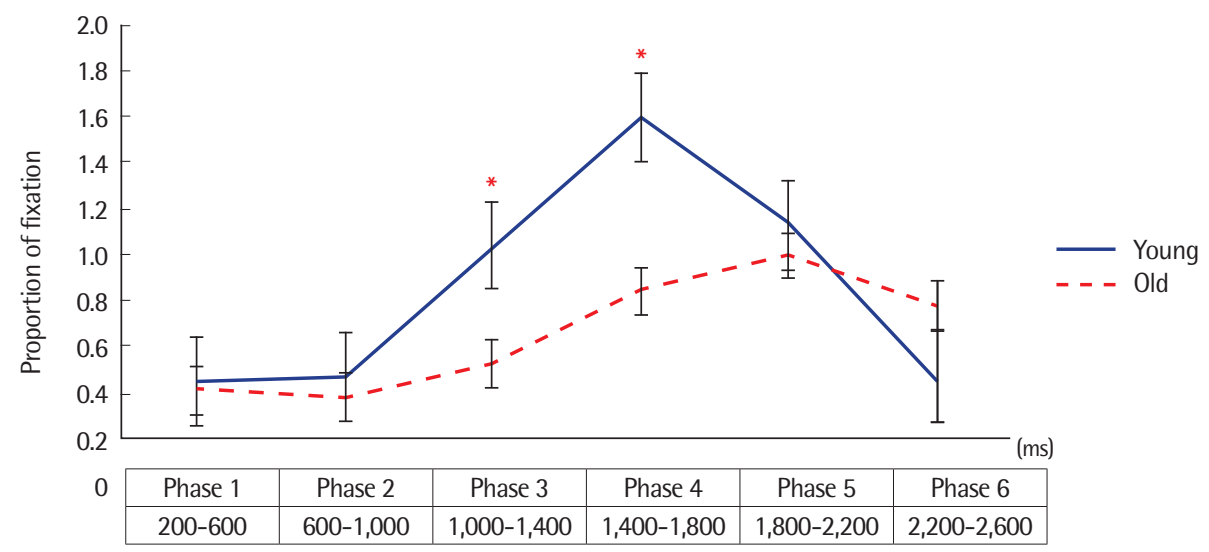

Figure 3. Mean proportion of fixations over time to the target for each group (error bar based on standard error). 
이원혼합분산분석 결과, 구간별 주효과는 통계적으로 유의하였 다 $\left(F_{(5,220)}=31.28, p<.001\right)$. Bonferroni로 사후검정을 실시하였으 며, 그 결과는 Table 6에 제시하였다. 사후검정 시 다중비교(multiple comparison)로 인해 나타나는 제 1 종오류(type 1 error)의 증가 를 통제하기 위해 Bonferroni alpha correction을 적용하여 유의수 준을 $.003(=.05 / 15)$ 으로 유의성 검정을 하였다. 그 결과, 구간1과 구간2, 구간1과 구간6 간 유의한 차이가 없었으나, 구간1에 비해 구 간3, 구간4, 구간5에서는 유의한 차이가 있었다. 즉, 목표자극을 구 간1에 비해 구간3, 구간4, 구간5에서 더 오래 응시했음을 알 수 있 다. 구간2에서는 구간3, 구간4, 구간5와 유의한 차이가 있었다. 즉, 목표자극을 구간2에 비해 구간3, 구간4, 구간5에서 더 오래 응시했 음을 알 수 있다. 구간3에서는 구간4와 유의한 차이가 있었으며, 구 간4에서는 구간6과, 구간5에서는 구간6과 유의한 차이를 보였다. 즉, 목표자극을 구간3에 비해 구간4에서 더 오래 응시하였으며, 구 간4에 비해 구간6에서, 구간5에 비해 구간6에서 덜 응시했음을 알 수 있다. 반면, 청년층과 노년층 두 집단 간 주효과가 통계적으로 유 의하지 않았다 $\left(F_{(1,44)}=3.60, p>.05\right)$.

구간과 집단 간 이차 상호작용이 통계적으로 유의하였다 $\left(F_{(5.220)}=\right.$ $10.26, p<.001)$. 이차 상호작용 검증을 위해 사후검정을 두 가지 측 면에서 살펴보았다. 첫째, 각 구간별로 집단 간 차이를 살펴보기 위 해 독립표본 $t$-검정을 시행하였다. 그 결과는 Table 7에 제시하였다. 결과적으로 구간3 (1,000-1,400 ms)과 구간4 $(1,400-1,800 \mathrm{~ms})$ 에서 집단 간 차이가 통계적으로 유의하였다. 즉, 구간3과 구간4에서 청

Table 6. Results of pairwise comparison with Bonferroni correction

\begin{tabular}{|c|c|c|c|c|c|}
\hline & Phase 2 & Phase 3 & Phase 4 & Phase 5 & Phase 6 \\
\hline Phase 1 & & $* *$ & *** & $* *$ & \\
\hline Phase 2 & & $* *$ & $* *$ & $* *$ & \\
\hline Phase 3 & & & $* *$ & & \\
\hline Phase 4 & & & & & $* *$ \\
\hline Phase 5 & & & & & $* *$ \\
\hline
\end{tabular}

${ }^{* *} p<.003$.

Table 7. Group differences on proportion of fixation to the target depending on the phases

\begin{tabular}{lc}
\hline & Significance \\
\hline Phase $1(200-600 \mathrm{~ms})$ & .591 \\
Phase $2(600-1,000 \mathrm{~ms})$ & .344 \\
Phase $3(1,000-1,400 \mathrm{~ms})$ & $.000^{* * *}($ Young $>0 \mathrm{ld})$ \\
Phase $4(1,400-1,800 \mathrm{~ms})$ & $.000^{* * *}$ (Young $>0$ Old $)$ \\
Phase $5(1,800-2,200 \mathrm{~ms})$ & .544 \\
Phase $6(2,200-2,600 \mathrm{~ms})$ & .071 \\
\hline
\end{tabular}

**** $p<.001$.
년층이 노년층에 비해 목표자극을 더 많이 응시하였다 $\left(t_{(44)}=4.29\right.$, $\left.p<.001 ; t_{(44)}=4.10, p<.001\right)$.

둘째, 각 집단별로 구간 진행에 따른 차이를 살펴보기 위해 대응 표본 $t$-검정(paired $t$-test)을 활용한 사후검정을 실시하였다. 그 결 과는 Table 8에 제시하였다. 사후검정 시 다중비교로 인해 나타나 는 제 1 종오류의 증가를 통제하기 위해 Bonferroni alpha correction 을 적용하여 유의수준을 $.01(=.05 / 5)$ 로 하여 유의성을 검정하였 다. 청년층은 구간2에서 구간4까지 통계적으로 유의하게 시선고정 비율이 증가했으며, 구간4에서 구간6까지는 유의하게 감소하였다. 반면 노년층의 경우 구간 3 과 구간 4 에서만 유의하게 증가함을 알 수 있었다.

\section{방해자극 유형에 따른 시선고정비율}

시선고정비율에서 방해자극 유형에 따라 구간별, 집단 간 차이 를 알아보기 위해, 청년층과 노년층을 집단 간 요인으로 지정하고, 6개의 구간(200-600 ms, $600-1,000 \mathrm{~ms}, 1,000-1,400 \mathrm{~ms}, 1,400-1,800$ $\mathrm{ms}, 1,800-2,200 \mathrm{~ms}, 2,200-2,600 \mathrm{~ms}$ )과 방해유형(의미유사, 음운 유사, 무관련)을 집단 내 요인으로 하여 삼원혼합분산분석을 실시 하였다.

Table 8. Group differences on proportion of fixation to the target depending on the phase progress

\begin{tabular}{lcc}
\hline & $\begin{array}{c}\text { Normal young group } \\
(\mathrm{N}=24)\end{array}$ & $\begin{array}{c}\text { Normal elderly group } \\
(\mathrm{N}=22)\end{array}$ \\
\hline Phase 1-Phase 2 & .805 & .575 \\
Phase 2-Phase 3 & $.000^{* * *}(2<3)$ & .035 \\
Phase 3-Phase 4 & $.000^{* * *}(3<4)$ & $.007^{* *}(3<4)$ \\
Phase 4-Phase 5 & $.000^{* * *}(4>5)$ & .094 \\
Phase 5-Phase 6 & $.000^{* * *}(5>6)$ & .013 \\
\hline
\end{tabular}

${ }^{* * *} p<.001,{ }^{* *} p<.01$.

Table 9. Descriptive data of proportion of fixations over time to the competitor objects

\begin{tabular}{lccccccc}
\hline & \multicolumn{3}{c}{ Normal young group $(\mathrm{N}=24)$} & & \multicolumn{3}{c}{ Normal elderly group (N=22) } \\
\cline { 2 - 3 } \cline { 7 - 8 } & $\mathrm{P}$ & $\mathrm{S}$ & $\mathrm{U}$ & & $\mathrm{P}$ & $\mathrm{S}$ & $\mathrm{U}$ \\
\hline Phase 1 & $.50(.25)$ & $.49(.27)$ & $.40(.28)$ & & $.45(.21)$ & $.43(.27)$ & $.40(.26)$ \\
Phase 2 & $.53(.28)$ & $.53(.26)$ & $.42(.23)$ & & $.55(.28)$ & $.49(.20)$ & $.40(.22)$ \\
Phase 3 & $.46(.21)$ & $.28(.16)$ & $.30(.19)$ & & $.45(.23)$ & $.31(.16)$ & $.28(.18)$ \\
Phase 4 & $.16(.12)$ & $.19(.13)$ & $.13(.09)$ & & $.15(.14)$ & $.19(.11)$ & $.15(.10)$ \\
Phase 5 & $.06(.10)$ & $.12(.11)$ & $.09(.16)$ & & $.06(.07)$ & $.14(.08)$ & $.10(.13)$ \\
Phase 6 & $.05(.09)$ & $.06(.11)$ & $.05(.10)$ & & $.07(.07)$ & $.10(.16)$ & $.08(.13)$ \\
\hline
\end{tabular}

Values are presented as mean (SD).

$\mathrm{P}=$ phonologically related to the target; $\mathrm{S}=$ semantically related to the target; $\mathrm{U}=$ unrelated semantically and phonologically to the target. 
Table 10. Pairwise comparisons of mean proportion of fixations for interference type over phases

\begin{tabular}{|c|c|c|c|c|c|}
\hline & Phase 2 & Phase 3 & Phase 4 & Phase 5 & Phase 6 \\
\hline Phase 1 & & $* *$ & $* * *$ & $* * *$ & $* * *$ \\
\hline Phase 2 & & $* * *$ & $* * *$ & $* * *$ & $* * *$ \\
\hline Phase 3 & & & $* * *$ & $* * *$ & $* * *$ \\
\hline Phase 4 & & & & $* * *$ & $* * *$ \\
\hline Phase 5 & & & & & \\
\hline
\end{tabular}

${ }^{* * *} p<.001,{ }^{* *} p<.01$.

Table 11. Pairwise comparisons of mean proportion of fixations for competitor over interference types

\begin{tabular}{lccc}
\hline & $\begin{array}{c}\text { Phonological } \\
\text { competitor }\end{array}$ & $\begin{array}{c}\text { Semantic } \\
\text { competitor }\end{array}$ & $\begin{array}{c}\text { Unrelated } \\
\text { competitor }\end{array}$ \\
\hline Phonological competitor & & & $* * *$ \\
Semantic competitor & $* * *$ & $* * *$ & \\
Unrelated competitor & $* * *$ & \\
\hline
\end{tabular}

${ }^{* * *} p<.001$.

삼원혼합분산분석 결과, 구간별 주효과가 통계적으로 유의하였 다 $\left(F_{(5.220)}=125.10, p<.001\right)$. 각 구간별 방해자극 유형에 따른 집단 간 차이의 기술통계(평균과 표준편차)는 Table 9에 제시하였다. Bonferroni로 사후검정을 실시하였으며, 사후검정 시 다중비교로 인해 나타나는 제 1 종오류의 증가를 통제하기 위해 Bonferroni alpha correction을 적용하여 유의수준을 .002 $(=.05 / 25)$ 로 유의성을 검정하 였다. 사후검정 결과는 Table 10 에 제시하였다. 그 결과, 구간 1 에서 는 구간2를 제외한 구간3, 구간 4 , 구간5, 구간6과 유의한 차이가 있 었다. 즉, 방해자극을 구간1에 비해 구간3, 구간 4 , 구간5, 구간6에서 더 짧게 응시했음을 알 수 있다. 구간2에서는 구간 3 , 구간 4 , 구간5, 구간6과 유의한 차이가 있었다. 구간3에서는 구간4, 구간5, 구간6 과 유의한 차이가 있었으며, 구간4에서는 구간 5 , 구간6과 유의한 차이를 보였다. 구간5와 구간6은 유의한 차이가 없었다. 즉, 구간이 진행함에 따라 방해자극의 시선고정비율이 점차적으로 감소하는 경향을 보였다. 구간1과 구간2에서 유의한 차이가 없는 것은 자극 제시 후, 방해자극이 활성화되어 구간1에서 구간2, 즉, 200-1,000 $\mathrm{ms}$ 까지 방해자극을 오래 응시했음을 알 수 있다. 구간5와 구간6에 서 유의한 차이가 없었음은 구간1에서 구간4, 즉, 200-1,800 ms까 지 단어재인 과제에서 필요한 언어처리가 이루어짐에 따라 이후에 는 방해자극을 적게 응시했다고 볼 수 있다.

삼원혼합분산분석 결과, 방해유형별 주효과가 통계적으로 유의 하였다 $\left(F_{(5.220)}=125.10, p<.001\right)$. Bonferroni를 통한 사후검정 결과 는 Table 11에 제시하였다. 방해자극 유형 중 음운유사와 무관련, 의미유사와 무관련 유형의 시선고정비율 간 유의한 차이가 나타났
Table 12. Pairwise comparisons of mean proportion of fixations for competitor over time to the interference types

\begin{tabular}{lccc}
\hline & $\begin{array}{c}\text { Phonological com- } \\
\text { petitor-Semantic } \\
\text { competitor }\end{array}$ & $\begin{array}{c}\text { Phonological com- } \\
\text { petitor-Unrelated } \\
\text { competitor }\end{array}$ & $\begin{array}{c}\text { Semantic competi- } \\
\text { tor-Unrelated } \\
\text { competitor }\end{array}$ \\
\hline Phase 1 & & & \\
Phase 2 & & $* *$ \\
Phase 3 & $* *$ & & \\
Phase 4 & & & \\
Phase 5 & & & \\
Phase 6 & & & \\
\hline
\end{tabular}

${ }^{* *} p<.002$.

다. 즉, 음운적, 의미적으로 유사한 방해자극에 음운적, 의미적으로 관련이 없는 자극에 비해 더 많이 간섭받았음을 알 수 있다.

구간과 방해자극 유형 간의 이차상호작용이 통계적으로 유의하 였다 $\left(F_{(10,440)}=5.90, p<.001\right)$. 구간별 방해자극의 유형에 대한 유의 한 차이가 있었는지 알아보기 위해 대응표본 $t$-검정을 활용한 사후 검정을 실시하였다. 그 결과는 Table 12와 같다. 구간3 (1,000-1,400 $\mathrm{ms}$ )에서 음운유사 방해자극과 의미유사 방해자극 시선고정비율 간 $\left(t_{(45)}=5.07, p<.001\right)$, 음운유사 방해자극과 무관련 방해자극 시 선고정비율 간 $\left(t_{(45)}=5.06, p<.001\right)$ 에 통계적으로 유의한차이가 있 었다. 즉, 구간3에서 음운유사 방해자극 시선고정비율(평균 .46)은 의미유사 방해자극의 시선고정비율(평균 0.3 )과 무관련 방해자극 시선고정비율(평균 .29)에 비해 유의하게 높았음을 알 수 있다.

반면, 집단 간 주효과 $\left(F_{(1,44)}=0, p>.05\right)$, 구간별 집단 간 상호작용 $\left(F_{(5,220)}=0.63, p>.05\right)$, 방해자극 유형별 집단 간 상호작용 $\left(F_{(2,88)}=\right.$ $0.17, p>.05)$, 구간에 따른 방해유형별 집단 간 상호작용 $\left(F_{(10,440)}=\right.$ $0.50, p>.05)$ 에서 각각 유의미한 주효과 및 상호작용효과는 나타나 지 않았다.

\section{논의 및 결론}

노화에 따른 언어처리 능력에 관한 연구가 다양하게 보고되어 왔다. 노년층의 언어처리와 관련하여 기존에 많이 사용된 방법은 피험자가 제시된 자극을 읽거나, 이해한 후, 말하기나 쓰기를 통해 산출된 반응에서 수행의 정반응률이나 반응시간을 측정하는 것이 었다. 이러한 방법은 반응산출을 하기 위한 부수적인 운동기능의 계획 및 실행능력 등이 요구된다는 점에서 순수한 언어처리 과정 을 알아보기에는 제약이 있고, 과제를 수행하는 동안 실시간 처리 과정을 확인하기 어렵다. 따라서 본 연구에서는 비침습적이며, 최 대한 자연스러운 실시간 언어처리 과정을 관찰할 수 있는 시선추적 
기법을 활용하여 청년층과 노년층을 대상으로 방해자극 유형에 따 른 단어재인 과제에서 집단 간 차이를 알아보고자 하였다.

우선 방해유형에 따른 단어재인 과제에서의 정반응률 및 반응 속도에서 청년층과 노년층 간 차이가 유의하였다. 즉, 청년층의 정 반응률이 노년층의 정반응률보다 유의하게 높았다. 또한, 노년층은 청년층에 비해 반응속도가 느렸다. 정반응률과 반응속도에서 집단 에 대한 주효과가 통계적으로 유의하였다. 즉, 노년층이 청년층에 비해 단어재인 과제 수행력이 저조하였다. 이러한 결과는 뇌영역 중 전두엽 기능의 감퇴로 인한 지각, 기억, 인지능력이 저조하기 때문 이라고도 볼 수 있다(Dempster, 1992; Faubert, 2002). 언어처리 과 정은 동시적으로 유입된 정보를 정확하고 신속한 자극들을 처리해 야 하는데, 노년층은 동시에 활성화된 여러 단어들 중 불필요한 의 미정보 또는 음운정보를 억제하는 능력이 부족하거나약화되어 있 다. 그렇기 때문에 단어를 재인하여 의미, 음운연결망에 접근하고 이를 통해 관련된 정보를 활성화시켜 반응을 산출하는 처리 과정 에서 청년층에 비해 경쟁 자극들로부터 더 많은 간섭을 받아 단어 재인과제의 수행력이 저조했음을 알 수 있다. 이는 노화에 따라 언 어처리 능력이 저하된다고 보고한 연구결과들과 일치한다(Feyereisen, 1997; Kim, 2015; Nicholas et al., 1997; Ramsay et al., 1999; Schmitter-Edgecombe et al., 2000; Yeon et al., 2017).

본 연구결과는 범주 일치 여부에 따른 그림-단어간섭 과제(picture-word interference task)를 통해 청년층과 노년층의 수행력 차 이를 살펴본 $\operatorname{Kim}$ (2015)의 연구결과와도 일치한다. 그림-단어간섭 과제란 방해자극을 효율적으로 억제(inhibition)하고, 목표자극에 주의를 기울여 정답에 해당하는 단어를 명명하는 과제이다. 그 결 과, 노년층이 청년층에 비해 정확도가 유의하게 낮았다. 이러한 결 과를 통해 연구자는 노화에 따라 목표 유지 능력의 감소와 언어처 리 및 판단과 같은 고차적 인지기능을 처리하는 능력이 감소하였다 고 보았다. 또한 목표자극(그림자극)과 방해자극(글자자극)이 서 로 동일 범주일 때, 노년층은 더 어려움을 보였다. 이는 범주 일치 여 부가 과제 수행에 있어 간섭의 효과를 더 크게 하는 요인이 될 수 있 음을 시사하였다. 또한 청년층, 중년층, 노년층의 단어 조건(규칙 단 어, 불규칙 단어, 규칙 비단어, 불규칙 비단어)에 따른 읽기 수행력 를 알아본 Yeon 등(2017)의 연구와 일부 일치하였다. Yeon 등(2017) 의 연구에 따르면 노년층은 청년층과 중년층에 비해 4 개의 단어조 건 중 불규칙 단어와 규칙 비단어에서 유의미한 수행력 저하를 보 였다. 자소와 음소가 대응되지 않는 불규칙 단어와 의미가 없는 규 칙 비단어를 읽는 것은 인지적 부담이 가중되는 것으로 설명할 수 있는데, 본 연구자는 정상 노화 과정에서 언어능력 및 인지기능의 감퇴와 주의력 감소는 어휘 통로의 정보 사용에 영향을 줄 수 있고,
복잡한 인지 처리 능력을 요구하는 읽기의 경우 노화에서 더 영향 을 받을 수 있음을 시사하였다. 종합해 보면, 어휘수준의 처리 과정 을 살펴본 본 연구와 어휘 처리 후 산출 단계(명명)가 포함된 Kim (2015)의 연구, 그리고 단어 조건에 따른 읽기 수행력을 다룬 Yeon 등(2017)의 연구는 공통적으로 노화에 따른 언어 및 인지능력의 저하가 과제를 수행함에 있어 영향을 준다는 것을 알 수 있다.

본 연구의 두 번째 목적은 방해유형에 따른 단어재인 과제에서 목표자극의 시선고정비율에 집단 간 차이가 있는지 살펴보는 것이 었다. 그 결과, 구간에 대한 주효과와 구간과 집단 간 상호작용이 통 계적으로 유의하였다. 각 구간별로 사후검정을 통해 확인한 결과, 구간3 (1,000-1,400 ms)과 구간4 $(1,400-1,800 \mathrm{~ms})$ 에서 노년층이 청 년층에 비해 목표자극의 시선고정비율이 유의하게 낮음을 알 수 있었다. 또한 구간 진행에 따른 집단별 차이를 알아보기 위해 사후 검정을 실시한 결과, 청년층은 구간2에서 구간4까지 통계적으로 유 의하게 시선고정비율이 증가했으며, 구간4에서 구간6까지는 유의 하게 감소하였다. 시선추적 양상에서 시선고정(fixation)이 정보의 획득 및 처리가 진행된다고 전제(Rayner, 1998)하므로, 청년층은 시 선고정비율이 유의하게 증가한 구간3과 구간4 (1,000-1,800 ms)까 지 언어처리 과정을 통해 단어재인 과제를 수행하였으나, 노년층의 경우 가장 시선고정비율이 높은 구간5 (1,800-2,200 ms)까지 점진 적으로 언어처리가 이루어지고 있음을 확인할 수 있었다. 즉, 노년 층이 청년층에 비해 단어재인 과제에서 언어처리 과정의 속도가 지 연된 것으로 볼 수 있다. 이러한 결과는 노화가 진행되면서, 기본적 인 정보처리 속도와 정확성이 떨어지고, 주의력이 약해진다는 것이 고 보고한 많은 연구결과와 일치한다(Balota \& Duchek, 1988; Giaquinto, Ranghi, \& Butler, 2007; Howard et al., 1986; Lott et al., 2001; Kim \& Lee, 2007; Reese \& Rodeheaver, 1985). Howard 등(1986)은 점화과제에서 청년층과 노년층을 대상으로 점화단어를 제시하고, 목표단어에 대한 어휘판단 시간을 측정하여 처리속도이론(processing speed theory; Salthouse, 1996)을 검증하였다. 처리속도이 론은 노화에 따른 인지기능의 저하로 인해 전반적인 처리속도가 지 연된다고 설명한다(Salthouse, 1996). 전체적으로 노인의 반응시간 이 느렸으며, 이는 의미 활성화의 발생 시점에 노화와 관련한 지연 이 있다고 보았다. 또한 본 연구는 한글단어재인의 어휘판단 과제 를 사용하여 청년층과 노년층의 차이를 연구한 Kim과 Lee (2007) 의 연구결과와도 일치하였다. 노인이 어휘판단시간이 청년보다 느 렸는데 이는 노인의 단어처리속도에 감퇴가 있음을 보여준다고 보 았다.

본 연구의 세 번째 목적은 방해유형에 따른 단어재인과제에서 구간별 방해자극의 시선고정비율에 집단 간 차이가 있는지 살펴보 
는 것이었다. 그 결과, 구간별 주효과가 통계적으로 유의하였다. Bonferroni로 사후검정을 실시한 결과, 구간이 진행함에 따라 방 해자극의 시선고정비율이 점차적으로 감소하는 경향을 보였다. 구 간1과 구간2에서 유의한 차이가 없는 것은 자극 제시 후, 방해자극 이 활성화되어 구간1부터 구간2까지인 200-800 ms까지 방해자극 을 오래 응시했음을 알 수 있다. 구간5와 구간6에서는 유의한 차이 가 없었는데 이는 구간1에서 구간4, 즉 200-1,800 ms까지 단어재인 과제에서 필요한 언어처리가 집중적으로 이루어짐에 따라 그 이후 에는 방해자극을 적게 응시했다고 볼 수 있다. 방해자극의 시선고 정비율이 감소하였다는 것은 단어재인 과제에서 목표자극과 음운 적, 의미적으로 관련된 자극의 간섭이 줄어들고, 목표자극에 집중 한다는 것을 의미한다.

또한, 방해자극 유형별 주효과가 통계적으로 유의하였다. Bonferroni를 활용한 사후검정 결과, 방해자극 유형 중 음운유사와 무 관련, 의미유사와 무관련 유형의 시선고정 비율 간 유의한 차이가 나타났다. 즉, 음운유사와 의미유사자극을 음운적, 의미적으로 관 련이 없는 자극에 비해 더 오래 응시했음을 알 수 있다. 음운적 또 는 의미적 유사자극에 시선을 고정한다는 것은 목표자극과 관련 된 유사자극을 효율적으로 억제(inhibition)하는 능력이 저하되어 과제 수행에 부정적 영향(방해)을 받는 것으로 해석할 수 있다. 이 렇게 방해를 받게 될 경우, 목표자극을 선택하는 속도가 지연되고, 정확도가 저조하게 나타날 수 있다(Slowiaczek \& Hamburger, 1992). 본 연구결과는 4 개의 그림 중에서 청각적으로 제시된 자극과 일치 하는 보기를 고르는 과제에서 관련 없는 단어에 비해 음운적으로 유사한 단어에 더 많이 시선을 고정한다는 선행연구 결과와 일치 한다고 볼 수 있다(Ben-David et al., 2011; Tanenhaus et al., 2000). 또한 청각자극을 듣고, 4 개의 그림 중 목표자극과 의미적으로 관련 된 자극을 관련 없는 단어에 비해 더 많이 응시했다는 선행연구 결 과와도 일치하였다(Yee \& Sedivy, 2006). 본 연구도구와 다른 그림단어간섭 과제를 사용하여 청년층의 어휘 접근 및 의미처리 과정 을 살펴보고자 한 여러 연구의 결과와도 일치하였다(Ahn, Lee, \& Yi, 2015; Hartendorp, Van der Stigchel, \& Postma, 2013; Koo \& Nam, 2007; Young, Ellis, Flude, McWeeny, \& Hay, 1986). 간섭 과 제란 목표자극(target stimuli)에 비해 방해자극(distractor stimuli) 이 깊이 처리되어 목표반응에 대한 간섭을 일으키게 되는 과제이 다. 이러한 연구들은 목표자극(예: 치마)은 의미적 관련이 없는 방 해자극(예: 화산)에 비해 목표자극에 대한 정보 처리를 크게 간섭 하기 때문에 명명시간이 지연되는 의미간섭효과가 발생한다고 보 고하였다. 결과적으로 본 연구 및 선행연구의 결과는 목표자극에 음운적, 의미적으로 관련된 방해자극이 관련 없는 방해자극에 비
해 더 오랜 시선고정, 즉 더 많은 간섭이 나타난다는 것이다.

구간과 방해자극 유형 간의 이차 상호작용이 통계적으로 유의하 였다. 구간별 방해자극의 유형에 대한 유의한 차이가 있었는지 알 아보기 위해 대응표본 $t$-검정을 활용한 사후검정을 실시한 결과, 구 간3 (1,000-1,400 ms)에서 음운유사 방해자극과 의미유사 방해자 극 시선고정비율 간, 음운유사 방해자극과 무관련 방해자극 시선 고정비율 간에 통계적으로 유의한 차이가 있었다. 즉, 구간 $3(1,000$ $1,400 \mathrm{~ms})$ 에서 음운유사 방해자극을 의미유사 방해자극, 무관련 방해자극에 비해 오래 응시했음을 알 수 있다. 이는 구간3에서 청 각자극과 일치하는 목표자극을 선택하는 과제 수행에 있어 음운 자극에 가장 방해를 받았다고 할 수 있다. 이러한 결과는 정상 성인 층을 대상으로 한 의미정보 및 음운정보가 포함된 작업기억 과제 연구결과와 일치하지 않았다. 즉, 음운적 정보보다 의미적 정보를 저장하고 처리하는 과제의 수행력이 높았다는 연구결과와 일치하 지 않았다(Barde \& Thompson-Schill, 2002; Crosson et al., 1999).

반면, 집단 간 주효과, 구간별 집단 간 상호작용, 방해자극 유형별 집단 간 상호작용, 구간에 따른 방해유형별 집단 간 상호작용에서 도 각각 유의미한 주효과 및 상호작용효과는 나타나지 않았다. 이 는 청년층과 노년층이 과제 수행에 있어 구간에 따라 방해자극의 시선을 고정하는 패턴에는 큰 차이가 없음을 나타낸다.

본 연구는 방해자극이 포함된 단어재인 과제를 시선추적기법으 로 실시하여, 청년층과 노년층의 정반응률 및 반응시간을 살펴보 고, 목표자극과 방해자극의 시선고정비율에 대해 분석하였다. 그 결과, 노년층이 청년층에 비해 정확도가 및 반응속도가 저조하였 다. 이는 노화로 인한 언어 및 인지능력의 저하로 사료된다. 이러한 결과는 단어재인 과제에서 방해자극을 효율적으로 억제하는 능력 이 저하되면 정확도 및 반응속도가 저하된다는 선행연구 결과를 뒷받침한다(Slowiaczek \& Hamburger, 1992). 또한 기존의 선행연구 와 동일하게 두 집단 모두 음운유사, 의미유사 자극을 관련이 없는 자극에 비해 더 오래 응시하였다. 하지만, 방해자극에 따른 집단 간 차이를 살펴본 상호작용 효과는 유의하지 않았다. 방해자극 유형 에 따른 단어재인 과제에서 유의한 결과가 나온 선행연구를 확인 해 본 결과, 실어증과 같은 신경학적 손상군에서 방해자극 유형에 따른 유의한 결과가 나타났다. 예로, Janse (2006)의 연구결과에 따 르면 베르니케 실어증 환자군은 브로카 실어증 환자군과 정상군과 달리 음운유사자극에 유의하게 영향을 받았다. 이는 Yee 등(2008) 의 연구결과와도 일치한다. 본 연구는 신경학적 손상군이 아닌 정 상 청년층과 노년층을 대상으로 실험을 진행하였다. 그 결과, 정반 응율과 반응시간에서는 통계적으로 유의한 집단 간 차이가 증명되 었고, 실시간 처리과정(online processing)을 시간대(time-window) 
별로 확인한 결과, 노년층의 어휘 처리 과정에서의 지연(delay)이 관 찰되었다. 그러나 정상 노년층에게 음운 및 의미 영역을 활성화하 는 부분에서는 정상 청년층과 비교하여 온라인 처리 과정에서 유 의한 차이가 나타날 정도로 손상이 뚜렷하지는 않았기 때문에 본 결과에 차이가 없던 것으로 해석된다. 결론적으로 본 연구결과는 정상 노년층이 청년층에 비해 정확도 및 반응시간에서 지연되지만, 음운론적 또는 의미론적 실시간 처리 능력은 유지하고 있다는 선 행연구 결과를 뒷받침한다(Burke \& Peters, 1986; Jeong \& Pyun, 2005; Lovelace \& Cooley, 1982; Park et al., 2002; Scialfa \& Margolis, 1986; Spieler \& Balota, 2000).

노년층의 설단현상 및 단어인출결함은 어휘에 접근하는 음운/의 미 경로 등의 손상을 비롯해 처리 속도 저하(slowed online processing) 등 다양한 기저의 손상에 따른 증상으로 나타날 수 있다. 따라 서, 본 연구는 노년층의 설단현상 및 단어인출결함의 기전을 살펴 보는데 오프라인 방법뿐만 아니라 온라인 처리과정에서 구간대별 로 실시간 처리 과정에서의 처리 속도 저하가 나타나는 구간을 살 펴보고, 방해자극 유형을 조절하여 음운 및 의미 경로의 상대적 손 상 여부를 파악하고자 하였다는 점에서 의의가 있다.

본 연구의 제한점 및 후속연구에 대한 제언은 다음과 같다. 우선, 본 연구에서는 연구 대상자인 청년층와 노년층이 각각 24 명과 22 명 으로 구성되었다. 제한된 연구대상자 수로 인해 본 연구에서 도출된 결과를 일반화시켜 적용하는 데에는 한계가 있다. 즉, 후속연구에서 는 연구결과를 일반화시키기 위해 각 집단별로 충분한 연구대상자 를 확보할 필요가 있다. 또한 정상군을 대상으로 한 본 연구를 바탕 으로 다양한 신경언어장애군을 대상으로 한 비교 연구가 필요할 것 이다. 다음으로 본 연구에서는 실험자극은 목표어휘 20 개, 의미적 관련 어휘 20 개, 음소적으로 관련된 어휘 20 개, 목표어휘와 의미적, 음소적으로 관련 없는 어휘 20 개로 총 80 개이며, 목표어휘는 5 개의 범주(동물, 과채류, 잡화, 교통수단, 학용품)로 한정하였다. 이에 모 든 범주에 있어서 동일한 연구결과가 나온다고 보기엔 성급한 결론 일 수 있다. 따라서 본 연구에서 사용된 실험자극 이외에 다양한 명 사를 활용한 후속연구가 필요할 것이다. 또한 본 연구에서는 시선추 적을 통해 정상 청년층과 노년층의 차이를 분석해 보았다. 하지만 후속연구에서는 시선추적과 사건 관련 전위(event-related potential)를 함께 측정하고 비교 및 분석한다면 언어처리 과정에 대한 심 도 있는 연구가 될 것이다. 마지막으로 본 연구에서는 오프라인 과 제에서 오류가 매우 적어서 오류만 따로 분석하기에 충분하지 않았 다. 추후 과제 난이도가 높은 이름대기 과제를 활용한다면 오류 분 석을 통해 노년층의 음운 및 의미 처리 과정에서의 실시간 처리 능 력을 살펴보는 의미 있는 연구로 발전될 수 있을 것으로 기대된다.

\section{REFERENCES}

Ahn, S. H., Lee, Y. J., \& Yi, D. J. (2015). Redundant interference: evidence for the co-activation model in a word-picture Stroop task. Korean Journal of Cognitive and Biological Psychology, 27(2), 313-319.

Akutsu, H., Legge, G. E., Ross, J. A., \& Schuebel, K. J. (1991). Psychophysics of reading. X. Effects of age-related changes in vision. Journal of Gerontology, 46(6), P325-P331.

Amso, D., Haas, S., \& Markant, J. (2014). An eye tracking investigation of developmental change in bottom-up attention orienting to faces in cluttered natural scenes. PLoS One, 9(1), e85701.

Balota, D. A., \& Duchek, J. M. (1988). Age-related differences in lexical access, spreading activation, and simple pronunciation. Psychology and Aging, 3(1), 84-93.

Barde, L. H., \& Thompson-Schill, S. L. (2002). Models of functional organization of the lateral prefrontal cortex in verbal working memory: evidence in favor of the process model. Journal of Cognitive Neuroscience, 14(7), 10541063.

Bayles, K. A., Tomoeda, C. K., Kaszniak, A. W., Stern, L. Z., \& Eagans, K. K. (1985). Verbal perseveration of dementia patients. Brain and Language, 25(1), 102-116.

Beier, M. E., \& Ackerman, P. L. (2001). Current-events knowledge in adults: an investigation of age, intelligence, and nonability determinants. Psychology and Aging, 16(4), 615-628.

Belmore, S. M. (1981). Age-related changes in processing explicit and implicit language. Journal of Gerontology, 36(3), 316-322.

Ben-David, B. M., Chambers, C. G., Daneman, M., Pichora-Fuller, M. K., Reingold, E. M., \& Schneider, B. A. (2011). Effects of aging and noise on real-time spoken word recognition: evidence from eye movements. Journal of Speech, Language, and Hearing Research, 54(1), 243-262.

Bowles, N. L., \& Poon, L. W. (1985). Aging and retrieval of words in semantic memory. Journal of Gerontology, 40(1), 71-77.

Brown, A. S. (1991). A review of the tip-of-the-tongue experience. Psychological Bulletin, 109(2), 204-223.

Brown, A. S., \& Nix, L. A. (1996). Age-related changes in the tip-of-the-tongue experience. The American Journal of Psychology, 109(1), 79-91.

Brown, R., \& McNeill, D. (1966). The "tip of the tongue" phenomenon. Journal of Verbal Learning and Verbal Behavior, 5(4), 325-337.

Burke, D. M., \& Peters, L. (1986). Word associations in old age: evidence for consistency in semantic encoding during adulthood. Psychology and Ag- 
ing, 1(4), 283-292.

Burke, D. M., MacKay, D. G., Worthley, J. S., \& Wade, E. (1991). On the tip of the tongue: What causes word finding failures in young and older adults? Journal of Memory and Language, 30(5), 542-579.

Caramazza, A., \& Miozzo, M. (1997). The relation between syntactic and phonological knowledge in lexical access: evidence from the tip-of-thetongue' phenomenon. Cognition, 64(3), 309-343.

Choi, S. Y., \& Koh, S. Y. (2009). The perceptual span during reading Korean sentences. Korean Journal of Cognitive Science, 20(4), 573-601.

Christensen, K. J., Multhaup, K. S., Nordstrom, S. K., \& Voss, K. A. (1991). A new cognitive battery for dementia: relative severity of deficits in Alzheimer's disease. Developmental Neuropsychology, 7(4), 435-449.

Cohen, G. (1979). Language comprehension in old age. Cognitive Psychology, 11(4), 412-429.

Cohen, G., \& Faulkner, D. (1986). Memory for proper names: age differences in retrieval. British Journal of Developmental Psychology, 4(2), 187-197.

Cooper, P. V. (1990). Discourse production and normal aging: performance on oral picture description tasks. Journal of Gerontology, 45(5), P210-P214.

Cooper, R. M. (1974). The control of eye fixation by the meaning of spoken language: a new methodology for the real-time investigation of speech perception, memory, and language processing. Cognitive Psychology, 6(1), 84-107.

Craik, F. I. M. (2017). A functional account of age differences in memory. In Memory, attention, and aging (pp. 147-157). New York, NY: Taylor \& Francis.

Craik, F. I. M., \& Byrd, M. (1982). Aging and cognitive deficits: the role of attentional resources. In F. I. M. Craik \& S. Trehub (Eds.), Aging and cognitive processes (pp. 191-211). New York, NY: Plenum Press.

Cross, E. S., \& Burke, D. M. (2004). Do alternative names block young and older adults' retrieval of proper names? Brain and Language, 89(1), 174181.

Crosson, B., Rao, S. M., Woodley, S. J., Rosen, A. C., Bobholz, J. A., Mayer, A., \& Cox, R. W. (1999). Mapping of semantic, phonological, and orthographic verbal working memory in normal adults with functional 52 magnetic resonance imaging. Neuropsychology, 13(2), 171-187.

Dempster, F. N. (1992). The rise and fall of the inhibitory mechanism: toward a unified theory of cognitive development and aging. Developmental Review, 12(1), 45-75.

Evrard, M. (2002). Ageing and lexical access to common and proper names in picture naming. Brain and Language, 81(1-3), 174-179.

Faubert, J. (2002). Visual perception and aging. Canadian Journal of Experi- mental Psychology, 56(3), 164-176.

Feyereisen, P. (1997). A meta-analytic procedure shows an age-related decline in picture naming: comments on Goulet, Ska, and Kahn (1994). Journal of Speech, Language, and Hearing Research, 40(6), 1328-1333.

Fox, C. (1947). Vocabulary ability in later maturity. Journal of Educational Psychology, 38(8), 482-492.

Giaquinto, S., Ranghi, F., \& Butler, S. (2007). Stability of word comprehension with age: an electrophysiological study. Mechanisms of Ageing and Development, 128(11-12), 628-636.

Glosser, G., \& Deser, T. (1992). A comparison of changes in macrolinguistic and microlinguistic aspects of discourse production in normal aging. Journal of Gerontology, 47(4), P266-P272.

Gordon, J. K., \& Kindred, N. K. (2011). Word retrieval in ageing: an exploration of the task constraint hypothesis. Aphasiology, 25(6-7), 774-788.

Hartendorp, M. O., Van der Stigchel, S., \& Postma, A. (2013). To what extent do we process the nondominant object in a morphed figure? Evidence from a picture-word interference task. Journal of Cognitive Psychology, 25(7), 843-860.

Heine, M. K., Ober, B. A., \& Shenaut, G. K. (1999). Naturally occurring and experimentally induced tip-of-the-tongue experiences in three adult age groups. Psychology and Aging, 14(3), 445-457.

Holmqvist, K., Nyström, M., Andersson, R., Dewhurst, R., Jarodzka, H., \& Van de Weijer, J. (2011). Eye tracking: a comprehensive guide to methods and measures. Oxford: Oxford University Press.

Hough, M. S. (2007). Incidence of word finding deficits in normal aging. Folia Phoniatrica et Logopaedica, 59(1), 10-19.

Howard, D. V., Shaw, R. J., \& Heisey, J. G. (1986). Aging and the time course of semantic activation. Journal of Gerontology, 41(2), 195-203.

Humes, L. E., \& Floyd, S. S. (2005). Measures of working memory, sequence learning, and speech recognition in the elderly. Journal of Speech, Language, and Hearing Research, 48(1), 224-235.

Jang, P. H. (2012). A study on visual reaction of the motion graphic in CATV station ID (Master's thesis). Seoul National University of Science and Technology, Seoul, Korea.

Janse, E. (2006). Lexical competition effects in aphasia: deactivation of lexical candidates in spoken word processing. Brain and Language, 97(1), 1-11.

Jeong, H. S. (2004). How aging affects human learning ability? Korean Journal of Cognitive and Biological Psychology, 16(4), 435-450.

Jeong, H. S., \& Pyun, J. Y. (2005). Recall and interpretation of narrative texts in college students, middle-aged, and older adults groups. Korean Journal 
of Cognitive and Biological Psychology, 17(4), 509-527.

Kang, S. N., \& Yim, D. (2018). Reading comprehension and reading processing of school-aged children with specific language impairment using eye tracker. Communication Sciences \& Disorders, 23(4), 914-928.

Kang, Y. (2006). A normative study of the Korean-Mini Mental State Examination (K-MMSE) in the elderly. Korean Journal of Psychology: General, 25(2), 1-12.

Kang, Y., \& Na, D. L. (2003). Seoul Neuropsychological Screening Battery. Seoul: Human Brain Research \& Consulting Co.

Kang, Y., Na, D. L., \& Hahn, S. (1997). A validity study on the Korean MiniMental State Examination (K-MMSE) in dementia patients. Journal of the Korean Neurological Association, 15(2), 300-308.

Kang, Y., Jahng, S., \& Na, D. L. (2012). Seoul neuropsychological screening battery, 2nd Edition (SNSB-II). Seoul: Human Brain Research \& Consulting Co.

Kaplan, E., Goodglass, H., \& Weintraub, S. (1983). Boston Naming Test. Philadelphia, PA: Lea \& Febiger.

Kim, O. H. (2015). Semantic interference effect in picture-word naming tasks between youth and elderly (Master's thesis). Dankook University, Yongin, Korea.

Kim, S. J., \& Choi, H. (2012). Characteristics of verbal definitions in normal elderly Koreans. Korean Journal of Communication \& Disorders, 17(1), 107117.

Kim, S. K., \& Lee, H. Y. (2007). The semantic priming effects of young and older adults in Korean word recognition. Korean Journal of Cognitive and Biological Psychology, 19(19), 279-297.

Kim, S. K., \& Lee, H. Y. (2007). The semantic priming effects of young and older adults in Korean word recognition. Korean Journal of Cognitive and Biological Psychology, 19(4), 279-297.

Kim, Y. S., \& Koh, S. R. (2007). The Korean relative clause processing strategy: an eye-tracking study. Korean Journal of Cognitive and Biological Psychology, 19(3), 233-249.

Ko, S. G., \& Kwon, J. H. (2006). The relation among memory beliefs, cognitive activity and memory performance in healthy older adults. Korean Journal of Clinical Psychology, 25(3), 747-764.

Koh, S., Hong, H., Yoon, S., \& Cho, B. (2008). The frequency effect in Korean noun eojeols: an eye-tracking study. Korean Journal of Cognitive and Biological Psychology, 20(1), 21-32.

Koh, S. R., \& Yoon, N. Y. (2007). The characteristics of eye-movement in Korean sentence reading: cluster length, word frequency, and landing posi- tion effects. Korean Journal of Cognitive Science, 18(4), 325-350.

Koh, S. R., Yoon, S. J., Min, C. H., Choi, K. S., Ko, S. H., \& Hwang, M. A. (2010). The characteristics of eye-movement during children read Korean texts. Korean Journal of Cognitive Science, 21(4), 481-503.

Koo, M. M., \& Nam, K. (2007). The locus of the word frequency effect in speech production: evidence from the picture-word interference task. Malsori, 62, 51-68.

Koo, S., \& Choi, H. (2015). Characteristics of spontaneous speech in Broca’s aphasic patients through interview and picture description tasks. Journal of Rehabilitation Research, 19(1), 281-296.

Lambon Ralph, M. A., Sage, K., \& Roberts, J. (2000). Classical anomia: a neuropsychological perspective on speech production. Neuropsychologia, 38(2), 186-202.

Lee, H., Kim, S., Lee, G., Jung, Y., \& Park, J. (2012). The age-related changes in cognitive function. Korean Journal of Cognitive and Biological Psycholo$g y, 24(2), 127-148$.

Lee, J. (2003). Effects of cue aspects and task types on prospective memory performances in normal aging. Journal of the Korea Gerontological Society, 23(4), 49-65.

Lee, S. (2001). Studies on Korean quantitative linguistics. Seoul: Seoul National University Press.

Levelt, W. J., Roelofs, A., \& Meyer, A. S. (1999). A theory of lexical access in speech production. Behavioral and Brain Sciences, 22(1), 1-38.

Lott, L. A., Schneck, M. E., HaegerstrÖm-portnoy, G., Brabyn, J. A., Gildengorin, G. L., \& West, C. G. (2001). Reading performance in older adults with good acuity. Optometry and Vision Science, 78(5), 316-324.

Lovelace, E. A., \& Cooley, S. (1982). Free associations of older adults to single words and conceptually related word triads. Journal of Gerontology, 37(4), 432-437.

Madden, D. J., Turkington, T. G., Provenzale, J. M., Denny, L. L., Langley, L. K., Hawk, T. C., \& Coleman, R. E. (2002). Aging and attentional guidance during visual search: functional neuroanatomy by positron emission tomography. Psychology and Aging, 17(1), 24-43.

Maylor, E. A. (1990). Age, blocking and the tip of the tongue state. British Journal of Psychology, 81(2), 123-134.

Nam, K. C., Seo, K. J., Choi, K. S., Lee, K. G., Kim, T. H., \& Lee, M. Y. (1997). The word length effect on Hangul word recognition. Korean Journal of Experimental \& Cognitive Psychology, 9(2), 1-18.

Nicholas, M., Barth, C., Obler, L. K., Au, R., \& Albert, M. L. (1997). Naming in normal aging and dementia of the Alzheimer's type. In H. Goodglass \& 
Hye Lyun Jo, et al. • Age-Related Differences in Word Recognition Task with Eye-Tracking

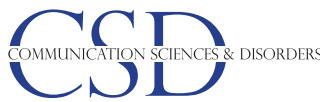

A. Wingfield (Eds.), Anomia (pp. 166-188). New York, NY: Academic Press.

Nicholas, M., Obler, L., Albert, M., \& Goodglass, H. (1985). Lexical retrieval in healthy aging. Cortex, 21(4), 595-606.

Oh, S. A. (2015). The effects of aging and mild cognitive impairment on tip-ofthe-tongue phenomenon in times of people naming task (Master's thesis). Daegu University Gyeongsan, Korea.

Park, D. C., Lautenschlager, G., Hedden, T., Davidson, N. S., Smith, A. D., \& Smith, P. K. (2002). Models of visuospatial and verbal memory across the adult life span. Psychology and Aging, 17(2), 299-320.

Park, E. J., Sung, J. E., \& Sim, H. S. (2014). Age-related changes in category decision-making abilities as a function of typicality and animacy of noun exemplars. Communication Sciences \& Disorders, 19(4), 523-531.

Park, J., Lee, K. E., \& Lee, H. W. (2013). The effects of aging on retrieval of phonological knowledge in Korean: the tip-of-the-tongue phenomenon in young and older adults. Korean Journal of Cognitive Science, 24(2), 111-132.

Park, M., \& Jin, Y. S. (2002). Age differences on implicit memory task performances in young and older adults. Korean Journal of Developmental Psychology, 14(4), 19-36.

Park, T. (2004). Cognitive neural mechanisms of aging. Korean Journal of Cognitive and Biological Psychology, 16(3), 317-336.

Ramsay, C. B., Nicholas, M., Au, R., Obler, L. K., \& Albert, M. L. (1999). Verb naming in normal aging. Applied Neuropsychology, 6(2), 57-67.

Rastle, K. G., \& Burke, D. M. (1996). Priming the tip of the tongue: effects of prior processing on word retrieval in young and older adults. Journal of Memory and Language, 35(4), 586-605.

Rayner, K. (1998). Eye movements in reading and information processing: 20 years of research. Psychological Bulletin, 124(3), 372-422.

Rayner, K., \& Sereno, S. C. (1994). Eye movements in reading: psycholinguistic studies. In M. A. Gernsbacher (Ed.), Handbook of psycholinguistics (pp. 57-81). San Diego, CA: Academic Press.

Reese, H. W., \& Rodeheaver, D. (1985). Problem solving and complex decision making. In J. E. Birren (Ed.), Handbook of the psychology of aging (2nd ed., pp. 474-499). San Diego, CA: Academic Press.

Salthouse, T. A. (1996). The processing-speed theory of adult age differences in cognition. Psychological Review, 103(3), 403-428.

Salthouse, T. A. (2004). What and when of cognitive aging. Current Directions in Psychological Science, 13(4), 140-144.

Sass, S. M., Legge, G. E., \& Lee, H. W. (2006). Low-vision reading speed: influences of linguistic inference and aging. Optometry and Vision Science, 83(3), 166-177.
Schmitter-Edgecombe, M., Vesneski, M., \& Jones, D. W. R. (2000). Aging and word-finding: a comparison of spontaneous and constrained naming tests. Archives of Clinical Neuropsychology, 15(6), 479-493.

Scialfa, C. T., \& Margolis, R. B. (1986). Age differences in the commonality of free associations. Experimental Aging Research, 12(2), 95-98.

Slowiaczek, L. M., \& Hamburger, M. (1992). Prelexical facilitation and lexical interference in auditory word recognition. Journal of Experimental Psychology: Learning Memory, and Cognition, 18(6), 1239-1250.

Snow, C. E. (1990). The development of definitional skill. Journal of Child Language, 17(3), 697-710.

Speranza, F., Daneman, M., \& Schneider, B. A. (2000). How aging affects the reading of words in noisy backgrounds. Psychology and Aging, 15(2), 253258.

Spieler, D. H., \& Balota, D. A. (2000). Factors influencing word naming in younger and older adults. Psychology and Aging, 15(2), 225-231.

Tanenhaus, M. K., Magnuson, J. S., Dahan, D., \& Chambers, C. (2000). Eye movements and lexical access in spoken-language comprehension: evaluating a linking hypothesis between fixations and linguistic processing. Journal of Psycholinguistic Research, 29(6), 557-580.

Verhaeghen, P. (2003). Aging and vocabulary score: a meta-analysis. Psychology and Aging, 18(2), 332-339.

Wingfield, A., \& Stine-Morrow, E. A. L. (2000). Language and speech. In F. 1. M. Craik, \& T. A. Salthouse (Eds.), The handbook of aging and cognition (2nd ed., pp. 396-416). New York, NY: Psychology Press.

Yee, E., Blumstein, S. E., \& Sedivy, J. C. (2008). Lexical-semantic activation in Broca’s and Wernicke's aphasia: evidence from eye movements. Journal of Cognitive Neuroscience, 20(4), 592-612.

Yee, E., \& Sedivy, J. (2001). Using eye movements to track the spread of semantic activation during spoken word recognition. Proceedings of the 13th Annual CUNY Sentence Processing Conference, Philadelphia, PA.

Yee, E., \& Sedivy, J. C. (2006). Eye movements to pictures reveal transient semantic activation during spoken word recognition. Journal of Experimental Psychology: Learning, Memory, and Cognition, 32(1), 1-14.

Yeon, E. J., Cho, E. B., Lee, S. J., Kim, S. W., Lee, Y., \& Yoon, J. H. (2017). Characteristics of word reading according to word condition in normal adults. Communication Sciences \& Disorders, 22(4), 730-744.

Yoon, N. Y., \& Koh, S. R. (2009). Eye-movements in reading easy and difficult texts. Korean Journal of Cognitive Science, 20(3), 291-307.

Young, A. W., Ellis, A. W., Flude, B. M., McWeeny, K. H., \& Hay, D. C. (1986). Face-name interference. Journal of Experimental Psychology: Human Per- 
ception and Performance, 12(4), 466-475.

Zec, R. F., Markwell, S. J., Burkett, N. R., \& Larsen, D. L. (2005). A longitudi- nal study of confrontation naming in the "normal" elderly. Journal of the

International Neuropsychological Society, 11(6), 716-726. 
Hye Lyun Jo, et al. • Age-Related Differences in Word Recognition Task with Eye-Tracking

Appendix 1. 실험자극 목록

\begin{tabular}{lcccc}
\hline & 목표어휘 & 음운유사 & 의미유사 & 무관련 \\
\hline 동물 & 다람쥐 & 다리미 & 호랑이 & 자물쇠 \\
& 거미 & 거울 & 무당벌레 & 피아노 \\
& 고래 & 고추 & 원숭이 & 선풍기 \\
& 나비 & 나사 & 개미 & 달력 \\
과채류 & 사과 & 사자 & 딸기 & 귀 \\
& 수박 & 수영 & 바나나 & 태극기 \\
& 마늘 & 마차 & 당근 & 병아리 \\
& 양파 & 양말 & 무 & 신호등 \\
의류/잡화 & 우산 & 우유 & 장화 & 시소 \\
& 가방 & 가지 & 안경 & 풍선 \\
& 단추 & 단풍잎 & 바늘 & 책 \\
& 바지 & 바퀴 & 치마 & 낙타 \\
& 버스 & 버섯 & 자동차 & 계산기 \\
교통수단 & 기차 & 기린 & 트럭 & 옷걸이 \\
& 비행기 & 비둘기 & 택시 & 수갑 \\
& 자전거 & 자판기 & 오토바이 & 시계 \\
& 연필 & 연탄 & 종이 & 호박 \\
& 물감 & 물개 & 붓 & 냄비 \\
& 볼펜 & 볼링 & 자 & 눈사람 \\
& 지우개 & 지팡이 & 가위 & 독수리 \\
\hline 문구류 & & & &
\end{tabular}




\title{
국문초록
}

\author{
시선추적을 활용한 방해자극 유형에 따른 단어재인 과제에서 청년층과 노년층 간 수행력 비교 \\ 조혜련 · 성지은 \\ 이화여자대학교 대학원 언어병리학과
}

배경 및 목적: 노화에 따른 노년층의 언어능력에 관해 단어재인 과정에 대한 연구가 다양하게 진행되어 왔으나, 실시간 언어처리 과정 에 대한 연구는 부족한 실정이다. 본 연구의 목적은 방해자극 유형에 따른 단어재인 과제에서 청년층과 노년층 간 수행력을 시선추적기 법을 통해 살펴보는 것이다. 방법: 정상 청년층 24 명과 정상 노년층 22 명을 대상으로, 방해자극 유형에 따른 단어재인 과제를 실시하였 다. 정반응률(\%)과 반응시간(ms), 시선추적기(eye-tracker)를 활용한 목표자극의 시선고정비율(proportion of fixation)과 방해자극의 시선고정비율을 유형별로 각각 산출하였다. 결과: 단어재인 과제 정확도 및 반응시간에서 노년층이 청년층에 비해 유의하게 저조한 수 행력을 보였다. 구간에 따른 집단 간 목표자극의 시선고정비율에 대한 이원혼합분산분석을 실시한 결과, 구간별 주효과와 구간과 집단 간 이차 상호작용이 유의하였다. 반면, 집단 간 주효과는 유의하지 않았다. 구간에 따른 집단 간 방해자극의 시선고정비율에 대한 삼원 혼합분산분석을 실시한 결과, 구간별 주효과, 방해자극 유형별 주효과, 구간과 방해유형 간 이차 상호작용이 유의하였다. 반면, 집단 간 주효과, 구간과 집단 간 이차 상호작용, 방해유형과 집단 간 이차 상호작용, 구간에 따른 방해유형과 집단 간 이차 상호작용이 모두 유의 하지 않았다. 논의 및 결론: 노년층의 경우, 정반응률과 반응시간에서 청년층에 비해 수행력이 감퇴하였고, 실시간 시선고정비율에서 또한 처리 속도 저하(slowed processing)가 관찰되었다. 하지만, 신경학적 손상이 분명한 환자군에서 관찰되었던 방해자극 유형에 따른 영향은 미비한 것으로 나타났다. 이는, 노년층의 경우, 음운 및 의미 방해자극을 억제하는 실시간 능력은 손상되지 않은 것으로 보이며, 단어재인 과정에서의 주요 손상 기제는 처리 속도 저하에 기인하는 것으로 해석된다.

핵심어: 단어재인, 시선추적기법, 시선고정비율(proportion of fixation), 노화

본 논문은 제 1 저자(조혜련)의 석사학위논문의 일부를 발췌한 것임.

본 논문 또는 저서는 2016년 대한민국 교육부와 한국연구재단의 지원을 받아수행된 연구임(No. NRF-2017S1A2A2038375).

\section{참고문헌}

강시내, 임동선(2018). 시선 추적기를 활용한 학령기 단순언어장애 아동의 이야기 읽기 이해력과 읽기 처리과정 연구. Communication Sciences \& Disorders, 23(4), 914-928.

강연욱(2006). K-MMSE (Korean-Mini Mental State Examination)의 노인 규준 연구. 한국심리학회지: 일반, 25(2), 1-12. 강연욱, 나덕렬(2003). 서울신경심리검사(Seoul Neuropsychological Screening Battery). 서울: 휴브알엔씨. 강연욱, 나덕렬, 한승혜(1997). 치매환자들을 대상으로 한 K-MMSE의 타당도연구. 대한신경과학회지, 15(2), 300-308. 강연욱, 장승민, 나덕렬(2012). 서울신경심리검사 2판(SNSB-II). 서울: 휴브알앤씨 고선규, 권정혜(2006). 노인의 기억 신념, 인지활동 및 기억 수행의 관계. 한국심리학회지: 임상, 25(3), 747-764. 고성룡, 윤낙영(2007). 우리 문장 읽기에서 안구 운동의 특성: 어절 길이, 단어 빈도 및 착지점 관련 효과. 인지과학, 18(4), 325-350. 고성룡, 윤소정, 민철홍, 최경순, 고선희, 황민아(2010). 어린이 글읽기에서 나타나는 안구운동의 특징. 인지과학, 21(4), 481-503. 고성룡, 홍효진, 윤소정, 조병환(2008). 우리글 명사 어절에서의 단어 빈도 효과: 안구운동 추적 연구. 한국심리학회지: 인지 및 생물, 20(1), 21-32. 구민모, 남기춘(2007). 말소리 산출에서 단어빈도효과의 위치: 그림-단어간섭과제에서 나온 증거. 말소리, 62, 51-68. 구서진, 최현주(2015). 대화와 그림설명 과제를 통한 브로카 실어증 환자의 자발화산출 특성. 재활복지, 19(1), 281-296. 김선경, 이혜원(2007). 한글단어재인에서 청년과 노인의 의미점화효과. 한국심리학회지: 인지 및 생물, 19(4), 279-297. 
김수정, 최현주(2012). 노년층의 명사 정의하기 특성. 언어청각장애연구, 17(1), 110-117.

김영삼, 고성룡(2007). “ 면서” 구문을 통해 본 관형절 처리 전략: 안구운동 추적 연구. 한국심리학회지: 인지 및 생물, 19(3), 233-249.

김오현(2015). 청년층과 노년층의 그림-단어 간섭과제를 통한 의미처리능력. 단국대학교 대학원 석사학위 논문.

남기춘, 서광준, 최기선, 이경인, 김태훈, 이만영(1997). 한글 단어 재인에서의 단어 길이 효과. 한국심리학회지, 인지 및 생물, 9(2), 1-18.

박민, 진영선(2002). 청년과 노인의 암묵기억 과제 수행에서의 연령차. 한국심리학회지: 발달, 14(4), 19-36.

박은지, 성지은, 심현섭(2014). 노화에 따른 범주판단능력의 차이: 의미전형성 및 생물성의 영향을 중심으로. Communication Sciences \& Disorders,

19(4), 523-531.

박지윤, 이고은, 이혜원(2013). 한국어 음운 정보 산출에서 노화의 영향. 인지과학, 24(2), 111-132.

박태진(2004). 노화의 인지신경기전. 한국심리학회지: 인지 및 실험, 16(3), 317-336.

안석환, 이윤정, 이도준(2015). 중복 간섭: 단어-사진 스트룹 과제를 통한 공동 활성화 모형검증. 한국심리학회지: 인지 및 생물, 27(2), 313-319.

연은주, 조은별, 이수정, 김선우, 이윤경, 윤지혜(2017). 정상 성인의 단어 조건에 따른 읽기 특성. Communication Sciences \& Disorders, 22(4), 730-

744.

오상아(2015). 노화와 경도인지장애가 사람이름 인출 시 설단현상에 미치는 영향. 대구대학교 대학원 석사학위논문.

윤낙영, 고성룡(2009). 난이도가 다른 덩이글 읽기에서의 안구운동 양상. 인지과학, 20(3), 291-307.

이상억(2001). 계량국어학 연구. 서울: 서울대학교출판부.

이종형(2003). 정상적 노화에 있어서 단서속성과 과제유형이 미래기억수행에 미치는 효과. 한국노년학, 23(4), 49-65.

이혜원, 김선경, 이고은, 정유진, 박지윤(2012). 연령에 따른 인지 변화 양상. 한국심리학회지: 인지 및 생물, 24(2), 127-148.

장필훈(2012). CATV Station ID에 나타난 모션그래픽의 시각적 반응 연구: 아이트래킹 실험을 중심으로. 서울과학기술대학교 대학원 석사학위논문. 정혜선(2004). 노화가 학습 능력에 미치는 영향. 한국심리학회지: 인지 및 생물, 16(4), 435-450.

정혜선, 편지영(2005). 대학생, 중년, 노인 집단의 이야기에 대한 기억과 해석. 한국심리학회지: 인지 및 생물, 17(4), 509-527.

최소영, 고성룡(2009). 우리글 읽기에서 지각 폭 연구. 인지과학, 20(4), 573-601.

\section{ORCID}

조혜련(http://orcid.org/0000-0003-2931-3994); 성지은(http://orcid.org/0000-0002-1734-0058) 